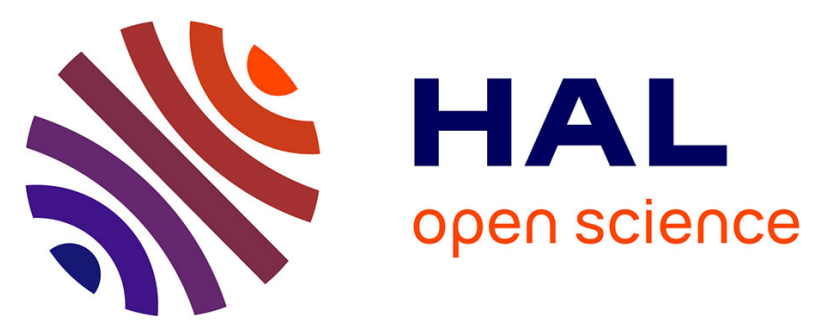

\title{
A combined experimental and theoretical study of the thermal cycloaddition of aryl azides with activated alkenes.
}

Sarah Zeghada, Ghenia Bentabed-Ababsa, Aïcha Derdour, Safer Abdelmounim, Luis R. Domingo, José A. Sáez, Thierry Roisnel, Ekhlass Nassar, Florence Mongin

\section{To cite this version:}

Sarah Zeghada, Ghenia Bentabed-Ababsa, Aïcha Derdour, Safer Abdelmounim, Luis R. Domingo, et al.. A combined experimental and theoretical study of the thermal cycloaddition of aryl azides with activated alkenes.. Organic \& Biomolecular Chemistry, 2011, 9 (11), pp.4295-4305. 10.1039/c1ob05176h . hal-00737037

\section{HAL Id: hal-00737037 https://hal.science/hal-00737037}

Submitted on 1 Aug 2014

HAL is a multi-disciplinary open access archive for the deposit and dissemination of scientific research documents, whether they are published or not. The documents may come from teaching and research institutions in France or abroad, or from public or private research centers.
L'archive ouverte pluridisciplinaire HAL, est destinée au dépôt et à la diffusion de documents scientifiques de niveau recherche, publiés ou non, émanant des établissements d'enseignement et de recherche français ou étrangers, des laboratoires publics ou privés. 


\title{
A combined experimental and theoretical study of the thermal cycloaddition of aryl azides with activated alkenes
}

\author{
Sarah Zeghada, ${ }^{a}$ Ghenia Bentabed-Ababsa, ${ }^{* a, b}$ Aïcha Derdour, ${ }^{a}$ Safer Abdelmounim, ${ }^{a}$ Luis R. Domingo, ${ }^{* c}$ \\ José A. Sáez, ${ }^{c}$ Thierry Roisnel, ${ }^{d}$ Ekhlass Nassar $^{e}$ and Florence Mongin* ${ }^{b}$ \\ ${ }_{5}$ Received (in $\left.X X X, X X X\right) X$ th $X X X X X X X X X 20 X X$, Accepted Xth $X X X X X X X X X 20 X X$ \\ DOI: 10.1039/b000000x
}

Reactions were performed from aryl azides on the one hand, and activated alkenes coming from $\beta$ dicarbonyl compounds or malonodinitrile on the other hand, either with recourse to conventional heating or to microwave activation, to afford 1-aryl-1H-1,2,3-triazoles. The mechanism and the regioselectivity of

10 the reactions involving $\beta$-dicarbonyl compounds have been theoretically studied using DFT methods at the B3LYP/6-31G* level: they are domino processes comprising a tautomeric equilibrium of the $\beta$ -

dicarbonyl compounds with their enol forms, a 1,3-dipolar cycloaddition of the enol forms with the aryl azides (high activation energy), and a dehydration process (lower activation energy). The effect of nonconventional activation ways on the degradation of 1,2,3-triazolines was next studied experimentally.

${ }_{15}$ Finally, some of the 1,2,3-triazoles such synthesized were evaluated for their bactericidal and cytotoxic activities.

\section{Introduction}

Cycloaddition reactions are one of the most important synthetic processes, with both synthetic and mechanistic interest in organic 20 chemistry. Among them, 1,3-dipolar cycloadditions (13DCs), whose general concept was introduced by Huisgen and coworkers in $1960 \mathrm{~s},{ }^{1}$ are versatile tools for building five-membered heterocycles. $^{2}$

1,2,3-Triazole occupies a special place in heterocyclic 25 chemistry because it is the core structure of many agents of various interests (use as pharmaceuticals, agrochemicals, dyes, corrosion inhibitors, sensors, photostabilizers...), and 13DC between azides and alkynes or enolizable compounds are important ways to generate this heterocycle. ${ }^{3}$

30

Table 1 Cycloaddition reaction of aryl azides 1a-d with acetylacetone (2a) and methyl acetoacetate (2b) performed at room temperature

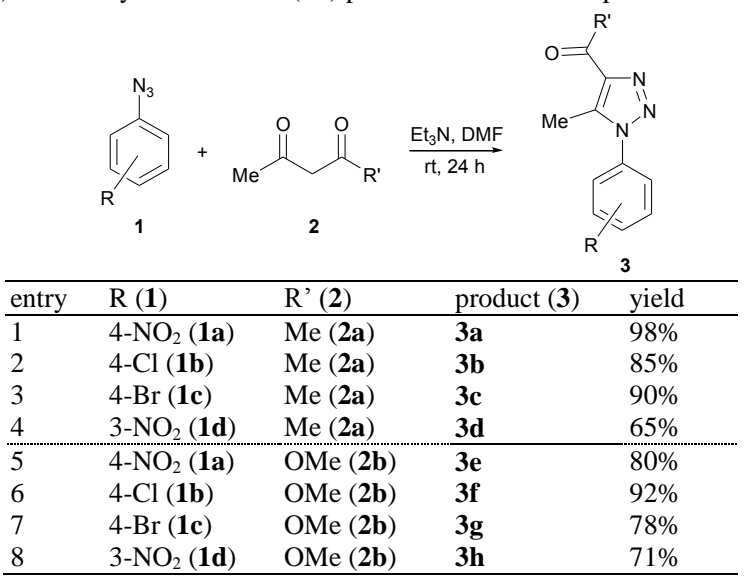

We focused on the synthesis of 1-aryl-5-methyl-1H-1,2,3triazoles bearing a ketone or an ester function at the 4 position, these compounds being both appreciated for their biological ${ }^{4}$ and photophysical $^{5}$ properties, and we decided to attempt their 35 syntheses with recourse to less conventional activating systems than oil bath heating such as microwaves and ultrasounds. The study was then extended to reactions with other dipolarophiles, and the mechanism of these reactions was investigated using DFT calculations. Finally, some of the triazoles such synthesized were 40 evaluated for their bactericidal and cytotoxic activities.

\section{Results and discussion}

\section{Synthetic aspects}

We first considered 13DC reactions between different aromatic azides on the one hand, and acetylacetone or methyl acetoacetate 45 on the other hand. Since the first 1,2,3-triazole formations by reaction between aryl azides and methylene-activated compounds in the early $1900 \mathrm{~s},{ }^{6}$ chemists have extended the scope of the reaction. $^{5,7}$ The latter proceeds in good yields at room temperature but requires long reaction times, and higher 50 temperatures lead to reduced conversions. ${ }^{7 \mathrm{k}}$ In addition, the efficiency of the reaction is lowered when electron-donating groups are present on the aryl azide. ${ }^{5}$

When 4-nitro-, 4-chloro-, 4-bromo-, and 3-nitrophenyl azides (1a-d) were treated with acetylacetone (2a, 2 equiv) in the 55 presence of triethylamine ( 2 equiv), and using DMF as solvent, the 1,2,3-triazoles 3a-d were isolated in high yields (Table 1, entries 1-4). As expected, a lower yield was noted when the nitro group was present at the 3 position instead of the 4 position. Similar results were recorded using methyl acetoacetate (2b) 
instead of acetylacetone to afford the derivatives $\mathbf{3 e - h}$ satisfactorily (Table 1, entries 5-8).

A rising number of articles have advocated the use of microwave technology in organic synthesis. Harsh conditions 5 such as high temperatures and long reaction times often required for cycloaddition reactions were generally improved using this technique. ${ }^{8}$ In order to reduce the reaction times, we thus decided to examine the effect of microwave irradiation on the reactions. Solvents being optional using this technology, the aryl azides 10 were simply microwave-heated in the presence of 2 equiv of acetylacetone or methyl acetoacetate, and 2 equiv of triethylamine at $160 \mathrm{~W}$. The precipitate formed after 5 min was then collected and washed with water. Whereas good results were obtained under these conditions from nitrophenyl azides 1a and

15 1d (Table 2, entries 1, 4, 5 and 8), moderate to low yields were observed using halogen-substituted phenyl azides $\mathbf{1 b}$ and 1c (Table 2, entries 2, 3, 6 and 7), and extended reaction times (15 min) and higher microwave powers did not allow to improve them.

20 The reactions under both types of conditions are regioselective. The nature of the regioisomer formed was established by NMR techniques: HMBC for the assignments of the methyl signals, and NOESY to confirm an interaction between the methyl group at the 5 position of the $1 H-1,2,3$-triazole ring and the phenyl ring. In

Table 2 Cycloaddition reaction of aryl azides 1a-d with acetylacetone (2a) and methyl acetoacetate (2b) performed under microwave irradiation

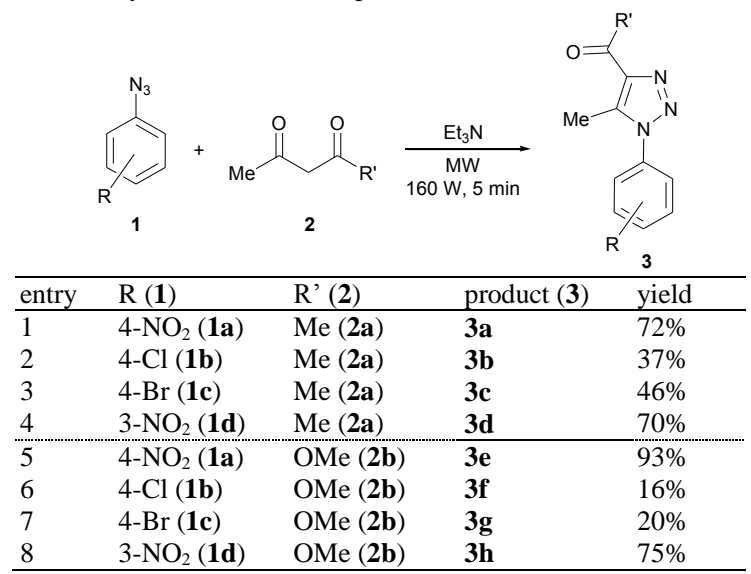

Table 3 Cycloaddition reaction of 4-nitrophenyl azide (1a) with $\alpha$ benzoylacetophenone (4a) and malonodinitrile $(\mathbf{4 b})$ performed at room temperature (with or without $\mathrm{CuCl}$ ) or under microwave irradiation

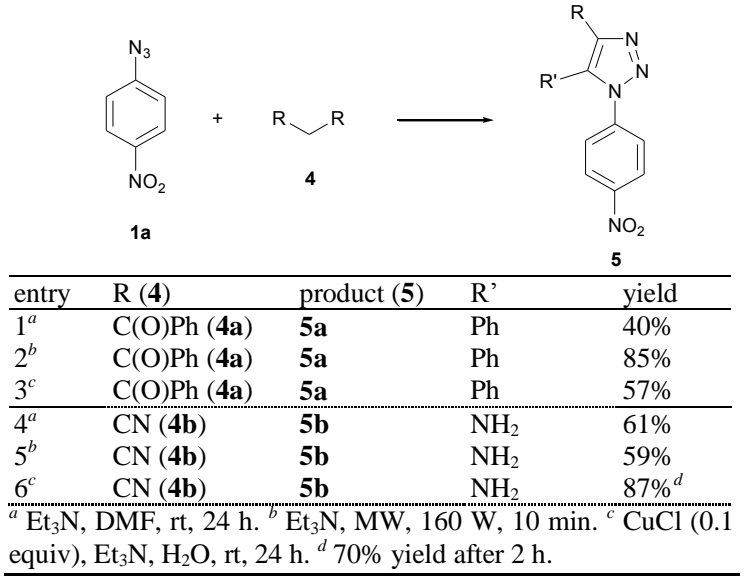

25 addition, the structures of the cycloadducts $\mathbf{3 b}, \mathbf{3 c}$, and $\mathbf{3 f}$ were identified unequivocally by $\mathrm{X}$-ray diffraction analysis.

$\alpha$-Benzoylacetophenone (4a) and malonodinitrile (4b) similarly reacted with 4-nitrophenyl azide (1a) to afford the compounds $\mathbf{5 a}$ and $\mathbf{5 b}$, respectively (Table 3 ). The former was 30 identified by X-ray diffraction analysis. It was isolated in 40 and $85 \%$ yield, respectively at room temperature and under microwave irradiation, under the conditions employed before (entries 1 and 2). Using a catalytic amount of copper(I) chloride 9 allowed to perform the reaction at room temperature in water in a 35 satisfying $57 \%$ yield (entry 3 ). The same three sets of conditions were similarly employed to furnish the derivative 7 in 61,59 and $70 \%$ yield, respectively (entries 4-6).

In the previous reactions, the 1,2,3-triazolines $\mathbf{6}$ were not observed due to elimination of water after the cycloaddition step 40 according to the mechanism depicted in Scheme 1. More generally, the isolation of 4,5-dihydro- $1 \mathrm{H}$-1,2,3-triazoles, which are compounds of biological interest, ${ }^{10}$ is not obvious, ${ }^{11}$ either due to subsequent elimination, or to cleavage with for example conversion to aziridines or diazo compounds. ${ }^{7 \mathrm{~h}, 12}$

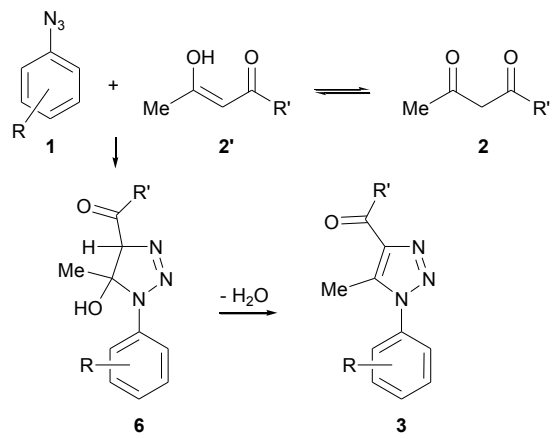

Scheme 1 Mechanism for the $1 H$-1,2,3-triazole formation. ${ }^{5}$

45 In order to study the effect of non-conventional activation ways on the degradation of 1,2,3-triazolines, we chose $\mathrm{N}$-(2hydroxyphenyl)acrylamide (7a), its 2-allyl derivative $\mathbf{7 b}$ and $\mathrm{N}$ vinylpyrrolidinone (7c), and examined their behavior toward 4nitrophenyl azide (1a) (Table 4). At the reflux temperature of an 50 apolar solvent such as toluene, the triazoline $\mathbf{8}$ was obtained from $N$-(2-hydroxyphenyl)acrylamide (7a) in a low $10 \%$ yield after 24 $\mathrm{h}$ reaction time (entry 1 ). Turning to acetone as solvent allowed the yield to reach $23 \%$ (entry 2 ). The reaction was also attempted without solvent, with recourse to microwave irradiation, but 55 without success, the starting materials being recovered (entry 3 ). We thus decided to turn to ultrasound activation. ${ }^{13}$ Sonicating the acetone reaction mixture for $24 \mathrm{~h}$ resulted in an improved but still moderate $34 \%$ yield (entry 4 ), due to the formation of other derivatives. By replacing the sonication by an activation based on 60 the catalytic use of a montmorillonite clay containing copper(II), Bentonite- $\mathrm{Cu}^{2+14}$ and by using toluene as solvent, the side reactions were partly discarded, and the yield was improved to $68 \%$ (entry 5 ).

$\mathrm{N}$-(2-Allyloxyphenyl)acrylamide (7b) regioselectively reacted 65 at the conjugated double bond with 4-nitrophenyl azide (1a). The reaction performed at the reflux temperature of acetone worked in a moderate $20 \%$ yield (entry 6), as observed with $\mathrm{N}$-(2hydroxyphenyl)acrylamide (7a) (entry 2). A similar yield being obtained using a catalytic amount of Bentonite- $\mathrm{Na}^{+}$in toluene at 


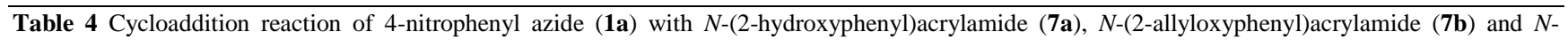
vinylpyrrolidinone (7c) (1 equiv)

\begin{tabular}{llll} 
entry & dipolarophile & conditions & $\begin{array}{l}\text { toluene, reflux, } 24 \mathrm{~h} \\
\text { acetone, reflux, 24 h } \\
\mathrm{MW}, 600 \mathrm{~W}, 10 \mathrm{~min} \\
\text { acetone, } \mathrm{US}, 24 \mathrm{~h} \\
\text { bentonite-Cu }\end{array}$ \\
\hline 1
\end{tabular}

"a 1-(4-Nitrophenyl)-1H-1,2,3-triazole (11) was isolated in $58 \%$ yield.<smiles>O=[N+]([O-])c1ccc(-n2ccnn2)cc1</smiles>

room temperature under ultrasound activation (entry 7), we turned to the use of Bentonite- $\mathrm{Cu}^{2+}$ : under the same reaction conditions, the triazoline 9 was isolated in $33 \%$ yield (entry 8 ).

Kadaba has shown that $N$-vinylamides can be used as 5 dipolarophiles in reactions with aryl azides, and that the subsequent elimination of carboxamide largely depends on the reaction conditions. ${ }^{15}$ Compared with $\mathrm{N}$-(2hydroxyphenyl)acrylamide, $N$-vinylpyrrolidinone (7c) (dominant $\mathrm{HOMO}_{\text {olefin }}-\mathrm{LUMO}_{\text {azide }}$ interactions) ${ }^{15}$ proved to react more 10 efficiently with 4-nitrophenyl azide (1a). When acetone was used as solvent, the cycloadduct $\mathbf{1 0}$ was provided in $63 \%$ yield after 24 $\mathrm{h}$ reflux (entry 9). In contrast, recourse to microwave irradiation without solvent resulted in the elimination of 2-pyrrolidinone, giving 1-(4-nitrophenyl)-1H-1,2,3-triazole (11) in 58\% yield 15 (entry 10). These results are different from those reported by Kadaba, where elimination takes place at the reflux temperature of ethanol, and formation of triazolines occurs in the absence of solvent at room temperature. ${ }^{15}$

\section{Calculations}

20 1) DFT study of the mechanism of the domino reactions of $\beta$ dicarbonyl compounds 2 with 4-nitrophenyl azide (1a).

The thermal reactions between the $\beta$-dicarbonyl compounds $\mathbf{2}$ and 4-nitrophenyl azide 1a are domino processes that comprise three consecutive reactions: i) a tautomeric equilibrium between

25 the $\beta$-dicarbonyl compounds 2 and their enolic forms $\mathbf{2}^{\prime}$, ii) a 13DC reaction between the corresponding enols $\mathbf{2}^{\prime}$ and 4nitrophenyl azide (1a) to give the 4,5-dihydro-1,2,3-triazoles $\mathbf{6}$, and iii) an acid-base catalyzed dehydration process to yield the final 1,2,3-triazoles 3 (see Scheme 2). In order to obtain 30 mechanistic details, as well as to explain the complete regioselectivity experimentally observed in the formation of the 1,2,3-triazoles $\mathbf{3}$, the two regioisomeric channels involved in the $13 \mathrm{DC}$ reactions were studied using DFT calculations at the B3LYP/6-31G* level.

35 The first reaction of this domino process is a tautomeric equilibrium between the keto and the enol forms of the $\beta$ dicarbonyl compounds 2 . The enols 2 ' can adopt an $E$ or $Z$ configuration at the C4-C5 double bond. The $Z$ isomers are 6.2 $\mathrm{kcal} / \mathrm{mol}(\mathbf{2} \mathbf{a}-\boldsymbol{Z})$ and $4.5 \mathrm{kcal} / \mathrm{mol}(\mathbf{2} ' \mathbf{b}-Z)$ more stable than the
40 corresponding $E$ isomers, due to the formation of an intramolecular hydrogen bond in the $Z$ isomers (see Table 5). The formation of the $\mathbf{2}^{\prime} \mathbf{a}-\boldsymbol{Z}$ and $\mathbf{2}^{\prime} \mathbf{b}-\boldsymbol{Z}$ enols is exothermic by -5.2 and $-0.2 \mathrm{kcal} / \mathrm{mol}$, respectively. (As some species involved in these domino reactions have ionic character, the discussion is 45 performed using the energies in acetonitrile).

Due to the asymmetry of the enols 2 ' and 4-nitrophenyl azide (1a), the subsequent $13 \mathrm{DC}$ reactions can take place through two regioisomeric channels associated with the approach of the $\mathrm{N} 1$ nitrogen of 4-nitrophenyl azide (1a) to the C5 or the C4 carbon 50 atoms of the enols 2', named 1 and 2, respectively. In order to analyze the role of the electron-withdrawing (EW) substitution in the aryl azides, the 13DC reaction of phenyl azide (1e) with the enol 2'a was also studied. In addition, the two regioisomeric channels associated with these 13DC reactions were studied in 55 order to explain the total regioselectivity experimentally observed (see Scheme 2).

The activation energies for the 13DC reactions of the enols 2' with the aryl azides $\mathbf{1}$ through the more favorable regioisomeric channels 1 via TS11 present very high values, between 22.2 to ${ }_{60} 24.7 \mathrm{kcal} / \mathrm{mol}$ (see Table 5). The $13 \mathrm{DC}$ reaction of the enol $\mathbf{2} \mathbf{a} \mathbf{a} \boldsymbol{Z}$ with phenyl azide (1e) has the largest activation energy, 24.7 $\mathrm{kcal} / \mathrm{mol}$ (TS11ea) (the anachronism " $\mathrm{e}$ " is used to distingue the species involved in the reactions of phenyl azide (1e)). A similar activation energy of $25.1 \mathrm{kcal} / \mathrm{mol}$ was obtained by single point 65 energy calculations at the MP3/6-31G* level. The inclusion of an EW nitro group on the aryl substituent decreases slightly this unfavorable energy, $22.2 \mathrm{kcal} / \mathrm{mol}$ (TS11a). The similar

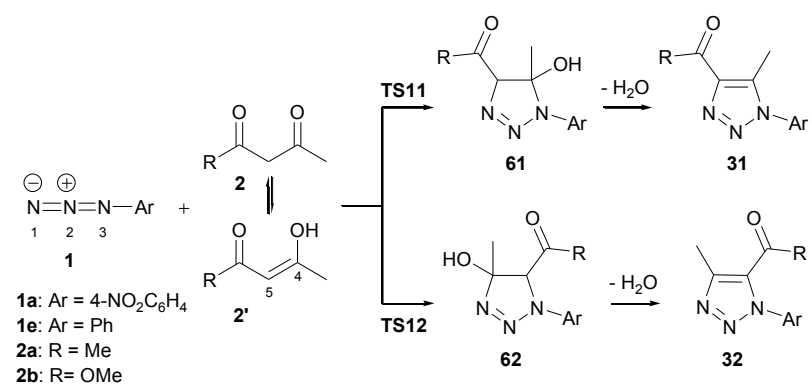

Scheme 2 Regioisomeric channels 1 and 2 associated with the thermal reactions of the $\beta$-dicarbonyl compounds $\mathbf{2}$ with the aryl azides $\mathbf{1}$. 
activation energy obtained for the $13 \mathrm{DC}$ reaction between the enol 2'b- $\boldsymbol{Z}$ and 4-nitrophenyl azide (1a), $22.2 \mathrm{kcal} / \mathrm{mol}$ (TS11b), accounts for a similar reactivity for the enols $\mathbf{2}^{\prime} \mathbf{b}-\boldsymbol{Z}$ and $\mathbf{2} \mathbf{a}-\boldsymbol{Z}$.

The activation energy for the $13 \mathrm{DC}$ reaction of the enol $\mathbf{2}$ 'a- $\boldsymbol{Z}$ 5 with phenyl azide (1e) via TS11ea is $c a .10 \mathrm{kcal} / \mathrm{mol}$ higher than that for the 13DC reaction of phenyl azide (1e) with methyl vinyl ether, as a model of electron-rich olefins, ${ }^{16}$ and higher than that obtained for the 13DC reaction of hydrazoic acid, $\mathrm{N}_{3} \mathrm{H}$, with ethylene, $19.5 \mathrm{kcal} / \mathrm{mol},{ }^{17}$ and with vinyl alcohol, $20.2 \mathrm{kcal} / \mathrm{mol} .{ }^{18}$

10 The activation energies associated with the more unfavorable regioisomeric channels 2 via TS12 are between 7.0 and 10.5 $\mathrm{kcal} / \mathrm{mol}$ higher in energy that those associated with the channels 1 (see Table 5). These high energy differences, which are higher than that found by Nguyen for the regioisomeric TSs associated 15 with the 13DC reactions between hydrazoic acid and vinyl alcohol, $\Delta \Delta \mathrm{E} 5.1 \mathrm{kcal} / \mathrm{mol},{ }^{18}$ are in complete agreement with the total regioselectivity experimentally observed.

From the enols 2 ' and the aryl azides $\mathbf{1}$, the formation of the cycloadducts (CA) $\mathbf{6 1}$ and $\mathbf{6 2}$ is slightly exothermic (see Table 5).

20 The last reaction of these domino processes is the acid-base catalyzed dehydration of the CA $\mathbf{6 1}$. These dehydration reactions proceed in three steps: i) a protonation at the keto or ester carbonyl oxygen atom of $\mathbf{6 1}$, which correspond to the most basic centers, ii) an E1 elimination of water at the hydroxy group of the 25 protonated 61, and iii) a hydrogen elimination at the vicinal C5 carbon atom to rebuild the C4-C5 double bond of the enol, thus yielding the final 1,2,3-triazoles 31 (see Scheme 3). We selected trimethylammonium cation as model of the acid catalyst.

The elimination process was studied for the thermal reactions 30 of the $\beta$-dicarbonyl compounds $\mathbf{2 a}, \mathbf{b}$ with 4-nitrophenyl azide (1a). Because similar results were obtained for both $\beta$-dicarbonyl

Table 5 B3LYP/6-31G* relative energies ( $\Delta \mathrm{E}$, in $\mathrm{kcal} / \mathrm{mol}$, relative i to 2 , ii to 1+2', and iii to IN11 or IN12) in gas phase and in solution, of the stationary points involved in the thermal domino reactions of the $\beta$ dicarbonyl compounds $\mathbf{2}$ with the aryl azides $\mathbf{1}$

\begin{tabular}{lcc}
\hline & $\Delta \mathrm{E}$ & $\Delta \mathrm{E}_{\text {solv }}$ \\
\hline i) enolization reaction & & \\
2'a-Z & -10.0 & -5.2 \\
2'a- $\boldsymbol{E}$ & 1.7 & 1.0 \\
2'b-Z & -1.9 & -0.2 \\
2'b-E & 7.8 & 4.3 \\
\hline ii) $13 D C$ reaction & \\
TS11ea & 23.6 & 24.7 \\
TS12ea & 31.9 & 31.7 \\
61ea & -3.3 & -3.0 \\
62ea & -0.4 & -4.3 \\
TS11a & 20.9 & 22.2 \\
TS12a & 32.4 & 32.7 \\
61a & -4.6 & -4.1 \\
62a & -1.7 & -5.4 \\
TS11b & 21.2 & 22.2 \\
TS12b & 30.0 & 30.8 \\
61b & -5.7 & -5.5 \\
62b & -5.1 & -7.0 \\
\hline iii) elimination reaction & & \\
TS21a & 4.1 & 5.4 \\
TS22a & 4.8 & 3.7 \\
31a & -11.1 & -18.0 \\
32a & -3.8 & -11.6 \\
TS21b & 3.3 & 5.5 \\
TS22b & 2.8 & 4.4 \\
31b & -9.7 & -17.9 \\
32b & -6.9 & -14.3 \\
\hline
\end{tabular}

compounds, only the results obtained for $1 \mathrm{a}$ will be discussed for simplicity. Anyway, the conclusions obtained for this catalyzed dehydration process could be applied to the rest of the reactions. 35 Protonation of 61a by trimethylammonium cation takes place at the carbonyl 08 oxygen atom, preserving the hydrogen bond between both oxygen atoms at the intermediate IN11a (see Scheme 3). Once protonated, IN11a loses a water molecule through an E1 mechanism via TS21a with a very low activation 40 energy of $5.4 \mathrm{kcal} / \mathrm{mol}$. After passing TS21a, the subsequent proton elimination to yield the final adduct 31a is downhill, being unfeasible to obtain the carbocation intermediate IN21a as a stationary point. This elimination reaction is very exothermic, $-18.0 \mathrm{kcal} / \mathrm{mol}$. This fact together with the favorable entropy 45 associated with the loss of a water molecule, makes irreversible the domino reaction.

Similar energy results were obtained for the water elimination in the regioisomeric CA 62a (see Table 5). Because the activation energies involved at the elimination reaction are lower than those ${ }_{50}$ involved in the $13 \mathrm{DC}$ reaction, it makes possible to discard a thermodynamic equilibration between the regioisomeric CAs 61a and 62a. Consequently, the formation of the final product 31a is kinetically controlled in the $13 \mathrm{DC}$ reaction. Finally, similar results were obtained for the elimination reaction at the 55 regioisomeric CAs $\mathbf{6 1 b}$ and $\mathbf{6 2} \mathbf{b}$ associated with the reaction of methyl acetoacetate (2b) (see Table 5).

The geometries of the TSs involved in the 13DC reaction between the enol $\mathbf{2}$ 'a- $\boldsymbol{Z}$ and 4-nitrophenyl azide (1a) are given in Figure 1, while the geometrical and electronic parameters of the ${ }_{60}$ TSs involved in the 13DC reactions are given in Table 6. The lengths of the forming bonds at the TSs are $1.974 \AA$ (N1-C5) and $2.251 \AA$ (N3-C4) at TS11a, and 1.906 (N1-C4) and 2.150 (N3C5) $\AA$ at TS12a. At these TSs the N-C bond formation at the unsubstituted N1 nitrogen atom of the aryl azide is slightly more 65 advanced than that at the substituted N3 nitrogen atom. ${ }^{18}$ Similar bond formation is observed at the other 13DC reactions (see Table 6). The asynchronicity on the bond-formation in the cycloaddition reactions can be measured by the difference of the lengths of the $\sigma$ forming bonds, $\Delta \mathrm{l}$. The corresponding values are 70 given in Table 6 . These values are in the range of 0.1 to 0.3 , indicating that the TSs correspond to concerted but asynchronous bond formation processes. For the 13DC reaction involving phenyl azide (1e), the TS12ea associated with the more unfavorable regioisomeric channel 2 is more asynchronous than 75 the TS11ea associated with the channel 1, while for the reactions involving 4-nitrophenyl azide (1a), TS11a associated with the more favorable regioisomeric channels 1 are more asynchronous.

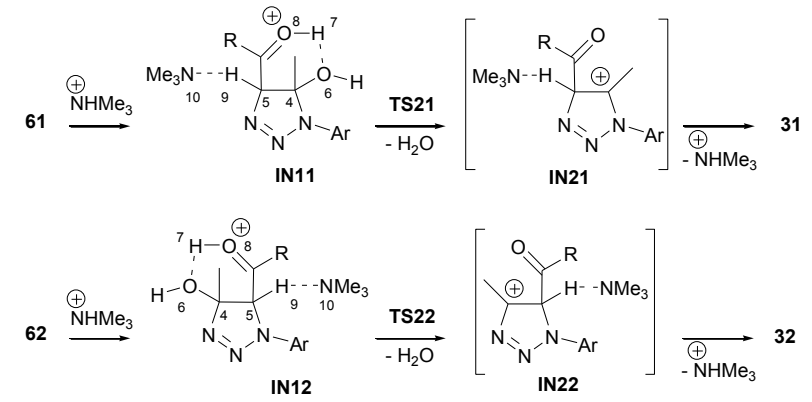

Scheme 3 Regioisomeric channels 1 and 2 associated with the elimination reactions of the CA 6 . 
Table 6 Lengths of the C-N forming bonds (in angstroms), asynchronicity ( $\Delta \mathrm{l})$, charge transfer (CT, in e), and bond orders (BO) of the C-N forming bonds involved in the 13DC reactions between the enols $\mathbf{2}$ ' and the aryl azides $\mathbf{1}$

\begin{tabular}{lcccccc}
\hline & N1-C5(4) & N3-C4(5) & $\Delta 1$ & CT & BO N1-C5(4) & BO N3-C4(5) \\
\hline TS11ea & 2.010 & 2.190 & 0.18 & 0.17 & 0.45 & 0.29 \\
TS12ea & 1.905 & 2.172 & 0.27 & 0.08 & 0.49 & 0.33 \\
TS11a & 1.974 & 2.251 & 0.28 & 0.26 & 0.48 & 0.25 \\
TS12a & 1.906 & 2.150 & 0.24 & 0.13 & 0.48 & 0.34 \\
TS11b & 1.977 & 2.264 & 0.29 & 0.25 & 0.48 & 0.25 \\
TS12b & 1.951 & 2.139 & 0.19 & 0.15 & 0.45 & 0.34 \\
\hline
\end{tabular}

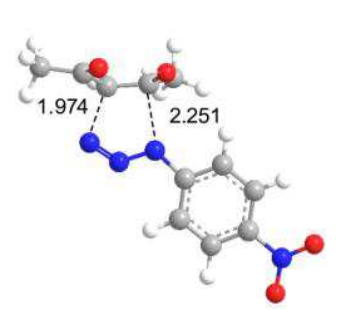

TS11a

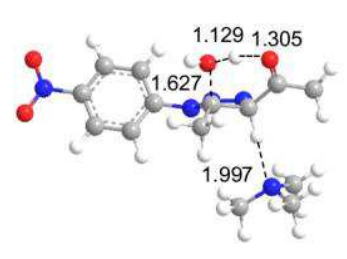

TS21a

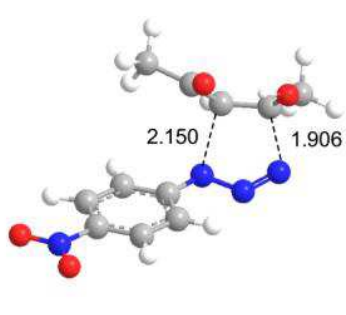

TS12a

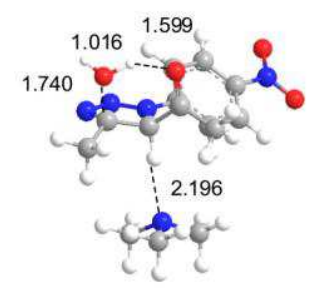

TS22a

Fig. 1 Transition states involved in the regioisomeric channels 1 and 2 associated with the 13DC reaction and water elimination steps of the thermal domino reaction between the $\beta$-dicarbonyl compound 2a with 4nitrophenyl azide (1a).

The extension on bond-formation at the TSs is provided by the bond order (BO). ${ }^{19}$ The $\mathrm{BO}$ values at the TSs associated with the 13DC reactions are given in Table 6. At the TSs associated with the more favorable regioisomeric channels 1 , the $\mathrm{BO}$ values 5 of the N1-C5 forming bonds are in the range of $0.45-0.48$, while those for the N3-C4 forming bonds are in the range of $0.25-$ 0.29 . The bond formation at the unsubstituted $\mathrm{N} 1$ is more advanced than at the substituted N3 atom. At the most favorable regioisomeric channels 1 , the TSs involving 4-nitrophenyl azide 10 (1a) are more advanced and more asynchronous. At the TSs associated with the more unfavorable regioisomeric channels 2, the $\mathrm{BO}$ values of the N1-C4 forming bonds are in the range of $0.45-0.49$, while those for the N3-C5 forming bonds are in the range of $0.33-0.34$. These TSs are slightly more advanced and 15 more synchronous than the regioisomeric TSs 1 .

The natural population analysis (NPA) allows us to evaluate the charge transfer (CT) at the TSs. The natural charges at the TSs were shared between the aryl azides $\mathbf{1}$ and the enols 2'. The CT, which takes place from the enols 2 ' to the azides $\mathbf{1}$, is given 20 in Table 6. The CT at the TSs associated with the more favorable regioisomeric channels 1 , between $0.17 \mathrm{e}$ and $0.26 \mathrm{e}$, is larger than that at the TSs associated with the regioisomeric channels 2, between $0.08 \mathrm{e}$ and $0.15 \mathrm{e}$. The more polar TSs are those associated with the 13DC reactions between the electron-rich ${ }_{25}$ enols $\mathbf{2}$ 'a- $\boldsymbol{Z}$ and $\mathbf{2}$ 'b- $\boldsymbol{Z}$ with electron-deficient (ED) 4-nitrophenyl

azide (1a).

Finally, the geometries of the TSs involved in the elimination reaction of the CAs 61a and 62a are given in Figure 1. The lengths of the breaking and forming bonds at the TSs involved in 30 the water elimination step are given in Table 7. At TS21a, the length of the C4-O6 breaking bond is $1.627 \AA$, while the lengths of the O8-H7 breaking and H7-O6 forming bonds are 1.305 and $1.129 \AA$, respectively. The length of the N10-H9 hydrogen bond is $1.997 \AA$. At TS22a, the length of the C4-O6 breaking bond is $351.740 \AA$, while the lengths of the O8-H7 breaking and H7-O6 forming bonds are 1.599 and $1.016 \AA$, respectively. The length of the N10-H9 hydrogen bond is $2.196 \AA$. At TS22a the water elimination process is more advanced than at TS21a.

Similar geometrical parameters were obtained for the water 40 elimination step of the domino reaction between the enol $\mathbf{2}^{\prime} \mathbf{b}$ and the aryl azide $\mathbf{1 a}$ (see Table 7).

Table 7 Lengths of the breaking and forming bonds (in angstroms) in the TSs involved in the water elimination step

\begin{tabular}{lcccc}
\hline & C4-O6 & O8-H7 & H7-O6 & H9-N10 \\
\hline TS21a & 1.627 & 1.305 & 1.129 & 1.997 \\
TS22a & 1.740 & 1.599 & 1.016 & 2.196 \\
TS21b & 1.619 & 1.280 & 1.145 & 1.941 \\
TS22b & 1.941 & 1.578 & 1.022 & 2.078 \\
\hline
\end{tabular}

2) Analysis based on the global and local reactivity indexes at the ground state of the reagents.

Recent studies carried out on cycloaddition reactions ${ }^{20}$ have 45 shown that the analysis of the reactivity indices defined within the conceptual $\mathrm{DFT}^{21}$ is a powerful tool to study the reactivity in polar cycloadditions. In Table 8 , the static global properties (electronic chemical potential, $\mu$, chemical hardness, $\eta$, global electrophilicity, $\omega$, and global nucleophilicity, N) of the enols 2 ' 50 and the aryl azides $\mathbf{1}$ are presented. The global properties of 4chlorophenyl azide (1b), 4-bromophenyl azide (1c) and hydrazoic acid, $\mathrm{N}_{3} \mathrm{H}$ are also included for comparative purposes.

The electronic chemical potential of 4-nitrophenyl azide (1a), $\mu=-0.1771 \mathrm{au}$, is lower than those for the enolates, $\mu=-0.1396$ 55 (2'a) and $-0.1306\left(\mathbf{2}^{\prime} \mathbf{b}\right)$ au, indicating thereby that along a polar 13DC reaction the net CT will take place from these enolates

Table 8 Electronic chemical potential, $(\mu$, in au), chemical hardness, $(\eta$, in au), global electrophilicity, $(\omega$, in eV), and global nucleophilicity, $(\mathrm{N}$, in $\mathrm{eV}$ ), of the enols $\mathbf{2}$ ' and the aryl azides $\mathbf{1}$

\begin{tabular}{lcccc}
\hline & $\mu(\mathrm{au})$ & $\eta(\mathrm{au})$ & $\omega(\mathrm{eV})$ & $\mathrm{N}(\mathrm{eV})$ \\
\hline $\mathbf{1 a}$ & -0.1771 & 0.1605 & 2.66 & 2.12 \\
$\mathbf{1 b}$ & -0.1393 & 0.1856 & 1.42 & 2.81 \\
$\mathbf{1 c}$ & -0.1385 & 0.1839 & 1.42 & 2.85 \\
$\mathrm{~N}_{3} \mathrm{H}$ & -0.1557 & 0.2404 & 1.37 & 1.62 \\
$\mathbf{2} \mathbf{a}-\boldsymbol{Z}$ & -0.1396 & 0.1968 & 1.35 & 2.65 \\
$\mathbf{1 e}$ & -0.1331 & 0.1897 & 1.27 & 2.92 \\
$\mathbf{2} \mathbf{2} \mathbf{b}-\boldsymbol{Z}$ & -0.1306 & 0.2082 & 1.11 & 2.74 \\
\hline
\end{tabular}


towards ED 4-nitrophenyl azide (1a), in clear agreement with the CT analysis performed at the TSs.

The electrophilicity and nucleophilicity indices of hydrazoic acid, $\mathrm{N}_{3} \mathrm{H}$, have low values, $\omega=1.37$ and $\mathrm{N}=1.62 \mathrm{eV}$. This 5 means that the simplest azide does not participate in polar processes. Phenyl azide (1e) shows a slight electrophilic deactivation, $\omega=1.27 \mathrm{eV}$, and a slight nucleophilic activation, $\mathrm{N}$ $=2.92 \mathrm{eV}$ (see Table 8). The inclusion of an halogen atom in the 4 position of benzene produces a slight electrophilic activation, $\omega$ $10=1.42 \mathrm{eV}$ for $\mathbf{1 b}$ and 1c. A more clear electrophilic activation is found at ED 4-nitrophenyl azide (1a), which has an $\omega=2.66 \mathrm{eV}$. On the other hand, the electrophilicity and nucleophilicity indices of the enols are $\omega=1.35$ and $N=2.65 \mathrm{eV}$ for $\mathbf{2} \mathbf{a}-\boldsymbol{Z}$, and $\omega=1.11$ and $\mathrm{N}=2.74 \mathrm{eV}$ for $\mathbf{2}^{\prime} \mathbf{b}-\mathbf{Z}$. Therefore, they will act as moderate 15 nucleophiles.

Analysis of the global reactivity indices indicates that these reactions will take place through cycloadditions with low polar character. Only the 13DC reactions involving the EW 4nitrophenyl group will present a large polar character.

20 Finally, the analysis of the local electrophilicity $\omega_{\mathrm{k}}$ at the electrophilic azides and the local nucleophilicity $\mathrm{N}_{\mathrm{k}}$ at the nucleophilic enols allows for a rationalization of the regioselectivity of cycloadditions. ${ }^{22}$ The values of the corresponding local indices are given in Table 9. The enols $2 \mathbf{2} \mathbf{a}, \mathbf{b}$ 25 present the largest nucleophilic activation at the $\mathrm{C} 5$ carbon atom, which corresponds with the $\beta$ carbon atom of the enols. On the other hand, 4-nitrophenyl azide (1a) presents the largest electrophilic activation at the terminal N1 nitrogen atom. ${ }^{23}$ Note that the N2 Nitrogen also presents an electrophilic activation. ${ }_{30}$ Consequently, the more favorable regioisomeric channel will correspond with the earlier formation of the N1-C5 $\sigma$ bonds than the N3-C4 one, in clear agreement with the energy results and with the asynchronicity found at the TSs.

Table 9 Local electrophilicity $\left(\omega_{\mathrm{k}}\right.$, in $\left.\mathrm{eV}\right)$ and nucleophilicity $\left(\mathrm{N}_{\mathrm{k}}\right.$, in $\left.\mathrm{eV}\right)$ indices of the enols $\mathbf{2}$ ' and the aryl azides $\mathbf{1}$

\begin{tabular}{ccccccc}
\hline & $\omega_{\mathrm{N} 1}$ & $\omega_{\mathrm{N} 2}$ & $\omega_{\mathrm{N} 3}$ & & $\mathrm{~N}_{\mathrm{C} 4}$ & $\mathrm{~N}_{\mathrm{C} 5}$ \\
\hline $\mathbf{1 e}$ & 0.62 & 0.44 & 0.13 & $\mathbf{2} \mathbf{a}$ & 0.32 & 1.32 \\
$\mathbf{1 a}$ & 1.30 & 0.92 & 0.27 & $\mathbf{2} \mathbf{b}$ & 0.37 & 1.39 \\
\hline
\end{tabular}

\section{3) Conclusions.}

35 The thermal reactions between acetylacetone (2a) and methyl acetoacetate (2b) with ED 4-nitrophenyl azide (1a) have been theoretically studied using DFT methods at the B3LYP/6-31G* level. They are domino processes that comprise three consecutive reactions: i) a tautomeric equilibrium of the $\beta$-dicarbonyl 40 compounds 2 with their enol forms 2 ', ii) a 13DC reaction of the enol forms 2 ' with 4-nitrophenyl azide (1a) to yield the 4,5dihydro-1,2,3-triazoles $\mathbf{6}$, and iii) an acid-base catalyzed dehydration process in $\mathbf{6}$ to yield the final 1,2,3-triazoles $\mathbf{3}$. For 13DC reactions, the two regioisomeric channels have been 45 studied.

The 13DC reactions present high activation energies, which are only slightly reduced by the use of ED 4-nitrophenyl azide (1a). The higher activation energies associated with the regioisomeric channels 2 prevent the formation of the 50 corresponding cycloadducts, these $13 \mathrm{DC}$ reactions being completely regioselective.

The lower activation energies of the water elimination step, respect to the $13 \mathrm{DC}$ reaction, together with the irreversible character of this dehydration process make possible to displace ${ }_{55}$ the reaction toward the formation of the final 1,2,3-triazoles 3 .

\section{Pharmacology}

Applying the agar plate diffusion technique, ${ }^{24}$ the newly synthesized compounds $\mathbf{3 a - h}$ and $\mathbf{5 a}$ were screened in vitro for their bactericidal activity against Gram positive bacteria ${ }_{60}$ (Staphylococcus aureus) and Gram negative bacteria (Escherichia Coli and Pseudomonas aeroginosa), and for their fungicidal activity towards Fusarium oxysporium, Aspergillus niger and Candida albicans (Table 10). The compounds 3a-c and 3e-g showed moderate bactericidal activities against ${ }_{65}$ Staphylococcus Aureus and Escherichia Coli compared to that of ciprofloxacin as a reference drug, and the compounds $\mathbf{3 d}, \mathbf{3 h}$ and 5a showed significant activities against Staphylococcus Aureus. All the compounds tested showed moderate fungicidal activities towards Fusarium oxysporium and Aspergillus niger compared to 70 that of nystin as a reference, except the compounds $3 \mathbf{b}-\mathbf{d}$ that showed significant activities against Fusarium oxysporium. All the compounds tested showed no activity against Candida albicans.

The same compounds were also tested against a human liver 75 carcinoma cell line (HEPG2) (Table 11). Moderate cytotoxic activities were observed, except for the compounds $\mathbf{3 d}$ and $\mathbf{5 a}$ (entries 4 and 9), which were found to have significant activities, compared to a reference drug (doxorubicin).

Table 10 Bactericidal and fungicidal activity ${ }^{a}$ of the compounds 3a-h, 5a, and ciprofloxacin and nystin

\begin{tabular}{llllllll}
\hline entry & compound & Staphylococcus aureus & Escherichia coli $\begin{array}{l}\text { Pseudomonas } \\
\text { aeroginosa }\end{array}$ & $\begin{array}{l}\text { Fusarium } \\
\text { oxysporium }\end{array}$ & $\begin{array}{l}\text { Aspergillus } \\
\text { niger }\end{array}$ & $\begin{array}{l}\text { Candida } \\
\text { albicans }\end{array}$ \\
\hline 1 & 3a & $22(++)$ & $18(++)$ & - & $19(++)$ & $19(++)$ & - \\
2 & $\mathbf{3 b}$ & $19(++)$ & $16(++)$ & - & $32(+++)$ & $19(++)$ & - \\
3 & $\mathbf{3 c}$ & $22(++)$ & $17(++)$ & - & $25(+++)$ & $20(++)$ & - \\
4 & $\mathbf{3 d}$ & $31(+++)$ & - & - & $26(+++)$ & $18(++)$ & - \\
5 & $\mathbf{3 e}$ & $16(++)$ & $15(++)$ & - & $22(++)$ & $17(++)$ & - \\
6 & $\mathbf{3 f}$ & $22(++)$ & $17(++)$ & - & $21(++)$ & $17(++)$ & - \\
7 & $\mathbf{3 g}$ & $21(++)$ & $20(++)$ & - & $21(++)$ & $17(++)$ & - \\
8 & $\mathbf{3 h}$ & $31(+++)$ & $15(++)$ & $16(++)$ & $18(++)$ & $18(++)$ & - \\
9 & $\mathbf{5 a}$ & $28(+++)$ & - & $15(++)$ & $20(++)$ & $18(++)$ & - \\
10 & ciprofloxacin & ++++ & ++++ & ++++ & - & - & - \\
11 & nystin & - & - & - & ++++ & ++++ & ++++
\end{tabular}

${ }^{a}$ The diameters of zones of inhibition are given in mm. Stock solution: $5 \mu \mathrm{g}$ in $1 \mathrm{~mL}$ of DMF. $0.1 \mathrm{~mL}$ of stock solution in each hole of each paper disk. +: < $15 \mathrm{~mm}$;++: 15-24 mm; +++: 25-34 mm; ++++: $35-44 \mathrm{~mm}$, etc. 
Table 11 In vitro cytotoxic activity $\left(\mathrm{IC}_{50}\right)^{a}$ of the compounds $\mathbf{3 a}-\mathbf{h}, \mathbf{5 a}$, and doxorubicin against a liver carcinoma cell line (HEPG2)

\begin{tabular}{lll}
\hline entry & compound & HEPG2 $\left(\mu \mathrm{g} \cdot \mathrm{mL}^{-1}\right)$ \\
\hline 1 & $\mathbf{3 a}$ & 3.34 \\
2 & $\mathbf{3 b}$ & 2.88 \\
3 & $\mathbf{3 c}$ & 2.92 \\
4 & $\mathbf{3 d}$ & 0.53 \\
5 & $\mathbf{3 e}$ & 2.46 \\
6 & $\mathbf{3 f}$ & 3.11 \\
7 & $\mathbf{3 g}$ & 2.24 \\
8 & $\mathbf{3 h}$ & 3.74 \\
9 & $\mathbf{5 a}$ & 0.81 \\
10 & doxorubicin & 0.60 \\
${ }^{a}$ IC50 is defined as the concentration which results in a \\
$50 \%$ decrease in cell number as compared with that of the \\
\multicolumn{3}{l}{ control structures in the absence of an inhibitor. } \\
\hline
\end{tabular}

\section{Conclusions}

Reactions performed between aryl azides on the one hand, and activated alkenes coming from $\beta$-dicarbonyl compounds or malonodinitrile on the other hand showed that microwave 5 activation allowed the reaction times to be considerably reduced in the case of nitrophenyl azides. With the help of DFT methods at the $\mathrm{B} 3 \mathrm{LYP} / 6-31 \mathrm{G}^{*}$ level, the mechanism of the reactions involving $\beta$-dicarbonyl compounds was studied, and their regioselectivity explained. They are domino processes that 10 comprise a tautomeric equilibrium of the $\beta$-dicarbonyl compound with its enol form, a 13DC with the aryl azide, and a dehydration process. The lower activation energy of the last step compared with the previous one helps to explain why 1,2,3-triazolines were not obtained, but the corresponding 1,2,3-triazoles. The effect of 15 non-conventional activation ways on the degradation of other 1,2,3-triazolines was next studied experimentally. Finally, some among the 1,2,3-triazoles evaluated exhibited interesting bactericidal and cytotoxic activities.

\section{Experimental}

\section{${ }_{20}$ Syntheses: general methods}

Liquid chromatography separations were achieved on silica gel Merck-Geduran Si $60(40-63 \mu \mathrm{m})$. Petrol refers to petroleum ether (bp 40-60 ${ }^{\circ} \mathrm{C}$ ). Melting points were measured on a Kofler apparatus. Infrared spectra were recorded on a JASCO FT/IR254200 apparatus, and main wavenumbers are given in $\mathrm{cm}^{-1}$. Nuclear Magnetic Resonance spectra were acquired using a Bruker AC-300 spectrometer $\left(300 \mathrm{MHz}\right.$ and $75 \mathrm{MHz}$ for ${ }^{1} \mathrm{H}$ and ${ }^{13} \mathrm{C}$ respectively). ${ }^{1} \mathrm{H}$ chemical shifts $(\delta)$ are given in ppm relative to the solvent residual peak, and ${ }^{13} \mathrm{C}$ chemical shifts relative to 30 the central peak of the solvent signal. Assignments of protons and carbons could be made on the basis of bidimensional techniques (NOESY, HMBC and HMQC experiments) using a Avance 500 spectrometer $\left(500 \mathrm{MHz}\right.$ and $125 \mathrm{MHz}$ for ${ }^{1} \mathrm{H}$ and ${ }^{13} \mathrm{C}$ respectively). High resolution mass spectra measurements were 35 recorded at the Centre Régional de Mesures Physiques de l'Ouest (CRMPO) in Rennes. Microwave reactions were performed in a Whirpool M571 domestic oven using open glass containers.

Bentonite- $\mathrm{Cu}^{2+14}$ was obtained as follows. Deposit bentonite $(60 \mathrm{~g})$ was dried $\left(80{ }^{\circ} \mathrm{C}, 18 \mathrm{~h}\right)$, crushed and sieved $(200 \mu \mathrm{m})$ 40 before treatment in order to remove carbonates (calcite and dolomite) at $\mathrm{pH} 2-3$ (addition of $0.1 \mathrm{~N} \mathrm{HCl}$ to a suspension in water) for $12 \mathrm{~h}$, and adjustment at $\mathrm{pH}$ 7. The clay was then scattered in aqueous $1 \mathrm{M} \mathrm{NaCl}$; three stirring of the suspension for $12 \mathrm{~h}$, centrifugation (4500 t.min ${ }^{-1}$ ) and washing sequences 45 were then performed. After two drying $\left(80{ }^{\circ} \mathrm{C}\right.$ and $\left.105{ }^{\circ} \mathrm{C}\right)$ crushing steps, resulting bentonite- $\mathrm{Na}^{+}$was suspended in water (50 g..$\left.^{-1}\right)$; the suspension was stirred and treated over $12 \mathrm{~h}$ by an aqueous $1 \mathrm{~N} \mathrm{CuCl}_{2}$ solution $(0.5 \mathrm{~L})$. This was repeated three times after decantation and removal of the supernatant liquid. 50 Bentonite- $\mathrm{Cu}^{2+}$ was washed using water, centrifuged (5000 t.min $\left.{ }^{-1}\right)$, and dried at $60{ }^{\circ} \mathrm{C}$. After crushing and sieving $(60 \mu \mathrm{m})$, it was dried again at $105^{\circ} \mathrm{C}$ for $12 \mathrm{~h}$.

Aryl azides were prepared according to the method of Nolting and Michel. ${ }^{25} \mathrm{~N}$-(2-Hydroxyphenyl)acrylamide (7a) was prepared 55 as described previously. ${ }^{26} \mathrm{~N}$-(2-Allyloxyphenyl)acrylamide (7b) was prepared using a described procedure, ${ }^{27}$ and recrystallized from 1:1 EtOH/ $\mathrm{H}_{2} \mathrm{O}$ : yield: $79 \%$; yellow powder, mp $37{ }^{\circ} \mathrm{C}$; IR (KBr): 1542, 1668, 3018, 3223; ${ }^{1} \mathrm{H}$ NMR (300 MHz, $\left.\mathrm{CDCl}_{3}\right) 4.78$ $(\mathrm{d}, 2 \mathrm{H}, \mathrm{J}=5.7 \mathrm{~Hz}), 5.47(\mathrm{dd}, 1 \mathrm{H}, \mathrm{J}=1.3$ and $17 \mathrm{~Hz}), 5.56(\mathrm{dd}$, ${ }_{60} 1 \mathrm{H}, \mathrm{J}=1.3$ and $\left.10 \mathrm{~Hz}\right), 5.91(\mathrm{~d}, 1 \mathrm{H}, \mathrm{J}=10 \mathrm{~Hz}), 6.27(\mathrm{ddd}, 1 \mathrm{H}, \mathrm{J}$ $=5.7,10$ and $17 \mathrm{~Hz}), 6.44(\mathrm{dd}, 2 \mathrm{H}, \mathrm{J}=10$ and $17 \mathrm{~Hz}), 6.55(\mathrm{~d}$, $1 \mathrm{H}, \mathrm{J}=17 \mathrm{~Hz}), 7.00-7.25(\mathrm{~m}, 4 \mathrm{H}), 8.03(\mathrm{~s}, 1 \mathrm{H}) ;{ }^{13} \mathrm{C} \mathrm{NMR}(75$ $\left.\mathrm{MHz}, \mathrm{CDCl}_{3}\right) 69.6\left(\mathrm{OCH}_{2}\right), 113.7\left(\mathrm{CH}_{2}\right), 115.5\left(\mathrm{CH}_{2}\right), 120.0$ $(\mathrm{CH}), 121.5(\mathrm{CH}), 122.4(\mathrm{CH}), 127.7(\mathrm{CH}), 130.1(\mathrm{CH}), 132.0$ ${ }_{65}(\mathrm{CH}), 135.6(\mathrm{C}), 153.5(\mathrm{C}), 168.0(\mathrm{C}=\mathrm{O})$.

General procedure 1. To the required methylene-activated compound $(10 \mathrm{mmol})$ and $\mathrm{Et}_{3} \mathrm{~N}(10 \mathrm{mmol})$ in $\mathrm{DMF}(2 \mathrm{~mL})$ was added the required azide $(5 \mathrm{mmol})$, and the mixture was stirred at room temperature for $24 \mathrm{~h}$. The precipitate was filtrated, washed 70 with $\mathrm{H}_{2} \mathrm{O}$, dried, and recrystallized from ${ }^{\mathrm{i}} \mathrm{PrOH}$.

General procedure 2. To the required methylene-activated compound $(10 \mathrm{mmol})$ and $\mathrm{Et}_{3} \mathrm{~N}(10 \mathrm{mmol})$ was added the required azide $(5 \mathrm{mmol})$, and the mixture was microwave-heated at $160 \mathrm{~W}$ for $5 \mathrm{~min}$. The precipitate was washed with $\mathrm{H}_{2} \mathrm{O}$ and 75 dried.

General procedure 3. To the required methylene-activated compound $(10 \mathrm{mmol})$ and $\mathrm{Et}_{3} \mathrm{~N}(10 \mathrm{mmol})$ in DMF $(2 \mathrm{~mL})$ was added the required azide $(5 \mathrm{mmol})$ and $\mathrm{CuCl}(1 \mathrm{mmol})$, and the mixture was stirred at room temperature for $17 \mathrm{~h}$. The precipitate 80 was filtrated, washed with $\mathrm{H}_{2} \mathrm{O}$, dried, and recrystallized from ${ }^{\mathrm{i}} \mathrm{PrOH}$.

5-Methyl-1-(4-nitrophenyl)-1H-1,2,3-triazole-4-ethanone (3a). Yield: $98 \%$ (general procedure 1), 72\% (general procedure 2). Yellow needles, mp $146{ }^{\circ} \mathrm{C}$ (lit. $\left.{ }^{28} 132-133{ }^{\circ} \mathrm{C}\right)$. IR (KBr): 1520 , 85 1680, 3102. ${ }^{1} \mathrm{H}$ NMR (300 MHz, $\mathrm{CDCl}_{3}$ ): 2.71 (s, 3H), 2.78 (s, $3 \mathrm{H}), 7.76(\mathrm{~d}, 2 \mathrm{H}, \mathrm{J}=8.8 \mathrm{~Hz}), 8.50(\mathrm{~d}, 2 \mathrm{H}, \mathrm{J}=8.8 \mathrm{~Hz}) .{ }^{13} \mathrm{C} \mathrm{NMR}$ $\left(75 \mathrm{MHz}, \mathrm{CDCl}_{3}\right): 10.8\left(\mathrm{CH}_{3}\right), 28.4\left(\mathrm{CH}_{3}\right), 125.7(2 \mathrm{CH}), 126.2$ (2 CH), 137.8 (C), 140.6 (C), 144.5 (C), $148.6(\mathrm{C}), 194.5(\mathrm{C}=\mathrm{O})$. HRMS (ESI): calcd for $\mathrm{C}_{11} \mathrm{H}_{10} \mathrm{~N}_{4} \mathrm{NaO}_{3}\left[(\mathrm{M}+\mathrm{Na})^{+\bullet}\right] 269.0651$, 90 found 269.0653 .

\section{5-Methyl-1-(4-chlorophenyl)-1H-1,2,3-triazole-4-ethanone}

(3b). Yield: $85 \%$ (general procedure 1), 37\% (general procedure 2). Pale yellow powder, mp $112{ }^{\circ} \mathrm{C}$ (lit. ${ }^{29} 108-110{ }^{\circ} \mathrm{C}$. IR ( $\mathrm{KBr}$ ): 836, 1550, 1687, 3104. ${ }^{1} \mathrm{H}$ NMR (300 MHz, $\left.\mathrm{CDCl}_{3}\right): 2.60$ (s, $\left.{ }_{95} 3 \mathrm{H}\right), 2.76(\mathrm{~s}, 3 \mathrm{H}), 7.41(\mathrm{~d}, 2 \mathrm{H}, \mathrm{J}=8.7 \mathrm{~Hz}), 7.57$ (d, 2H, J = 8.7 $\mathrm{Hz}) .{ }^{13} \mathrm{C}$ NMR $\left(75 \mathrm{MHz}, \mathrm{CDCl}_{3}\right): 10.1\left(\mathrm{CH}_{3}\right), 27.9\left(\mathrm{CH}_{3}\right), 126.5$ (2 CH), 130.0 (2 CH), $133.8(\mathrm{C}), 136.3(\mathrm{C}), 137.4(\mathrm{C}), 143.8(\mathrm{C})$, 
$194.3(\mathrm{C}=\mathrm{O})$. HRMS (ESI): calcd for $\mathrm{C}_{11} \mathrm{H}_{10}{ }^{35} \mathrm{ClN}_{3} \mathrm{NaO}$ $\left[(\mathrm{M}+\mathrm{Na})^{+\bullet}\right] 258.0410$, found 258.0413 .

\section{5-Methyl-1-(4-bromophenyl)-1H-1,2,3-triazole-4-ethanone}

(3c). Yield: $90 \%$ (general procedure 1), 46\% (general procedure 5 2). White powder, mp $116{ }^{\circ} \mathrm{C}$ (lit. ${ }^{29} 108-110{ }^{\circ} \mathrm{C}$. IR (KBr): 645 , 1549, 1688, 3092. ${ }^{1} \mathrm{H}$ NMR $\left(300 \mathrm{MHz}, \mathrm{CDCl}_{3}\right): 2.63$ (s, 3H), $2.78(\mathrm{~s}, 3 \mathrm{H}), 7.38(\mathrm{~d}, 2 \mathrm{H}, \mathrm{J}=8.6 \mathrm{~Hz}), 7.75(\mathrm{~d}, 2 \mathrm{H}, \mathrm{J}=8.6 \mathrm{~Hz})$. ${ }^{13} \mathrm{C} \mathrm{NMR}\left(75 \mathrm{MHz}, \mathrm{CDCl}_{3}\right): 10.6\left(\mathrm{CH}_{3}\right), 28.3\left(\mathrm{CH}_{3}\right), 124.7(\mathrm{C})$, 127.1 (2 CH), 133.4 (2 CH), 134.7 (C), 137.8 (C), $144.2(\mathrm{C})$, 10194.7 (C=O). HRMS (ESI): calcd for $\mathrm{C}_{11} \mathrm{H}_{10}{ }^{79} \mathrm{BrN}_{3} \mathrm{NaO}$ $\left[(\mathrm{M}+\mathrm{Na})^{+\bullet}\right] 301.9905$, found 301.9905 .

5-Methyl-1-(3-nitrophenyl)-1H-1,2,3-triazole-4-ethanone (3d). Yield: 65\% (general procedure 1), 70\% (general procedure 2). Yellow powder, mp $118{ }^{\circ} \mathrm{C}$. IR (KBr): 1561, 1721, 3096. ${ }^{1} \mathrm{H}$ $15 \mathrm{NMR}\left(300 \mathrm{MHz}, \mathrm{CDCl}_{3}\right): 2.71(\mathrm{~s}, 3 \mathrm{H}), 2.80$ (s, 3H), $7.89(\mathrm{~m}$, 2H), $7.75(\mathrm{~m}, 2 \mathrm{H}) .{ }^{13} \mathrm{C} \mathrm{NMR}\left(75 \mathrm{MHz}, \mathrm{CDCl}_{3}\right): 10.6\left(\mathrm{CH}_{3}\right), 28.4$ $\left(\mathrm{CH}_{3}\right), 102.6(\mathrm{C}), 120.7(\mathrm{CH}), 125.1(\mathrm{CH}), 131.3(\mathrm{CH}), 131.3$ (CH), 136.7 (C), 137.9 (C), 149.2 (C), 194.6 (C=O). HRMS (ESI): calcd for $\mathrm{C}_{11} \mathrm{H}_{10} \mathrm{~N}_{4} \mathrm{NaO}_{3}\left[(\mathrm{M}+\mathrm{Na})^{+\bullet}\right] 269.0651$, found 20269.0656 .

Methyl 5-methyl-1-(4-nitrophenyl)-1H-1,2,3-triazole-4carboxylate (3e). Yield: $80 \%$ (general procedure 1), $93 \%$ (general procedure 2). Yellow powder, mp $170{ }^{\circ} \mathrm{C}$ (lit. $\left.{ }^{30} 154{ }^{\circ} \mathrm{C}\right)$. IR (KBr): 1116, 1530, 1738, 3119. ${ }^{1} \mathrm{H}$ NMR (300 MHz, $\left.\mathrm{CDCl}_{3}\right)$ : $252.73(\mathrm{~s}, 3 \mathrm{H}), 4.04(\mathrm{~s}, 3 \mathrm{H}), 7.78(\mathrm{~d}, 2 \mathrm{H}, \mathrm{J}=9.1 \mathrm{~Hz}), 8.51(\mathrm{~d}, 2 \mathrm{H}, \mathrm{J}$ $=9.1 \mathrm{~Hz}) \cdot{ }^{13} \mathrm{C}$ NMR $\left(75 \mathrm{MHz}, \mathrm{CDCl}_{3}\right): 10.2\left(\mathrm{CH}_{3}\right), 52.3\left(\mathrm{CH}_{3}\right)$, $125.2(2 \mathrm{CH}), 125.9(2 \mathrm{CH}), 137.2(\mathrm{C}), 139.0(\mathrm{C}), 140.2(\mathrm{C})$, $148.3(\mathrm{C}), 161.8(\mathrm{C}=\mathrm{O})$. HRMS (ESI): calcd for $\mathrm{C}_{11} \mathrm{H}_{10} \mathrm{~N}_{4} \mathrm{NaO}_{4}$ $\left[(\mathrm{M}+\mathrm{Na})^{+\bullet}\right] 285.0600$, found 285.0604 .

${ }_{30}$ Methyl 5-methyl-1-(4-chlorophenyl)-1H-1,2,3-triazole-4carboxylate (3f). Yield: $92 \%$ (general procedure 1), $16 \%$ (general procedure 2). White powder, $\mathrm{mp} 188^{\circ} \mathrm{C}$. IR (KBr): 817 , 1095, 1561, 1725, 3104. ${ }^{1} \mathrm{H}$ NMR (300 MHz, $\left.\mathrm{CDCl}_{3}\right): 2.61(\mathrm{~s}$, $3 \mathrm{H}), 3.99$ (s, 3H), 7.42 (d, 2H, J = $8.8 \mathrm{~Hz}), 7.57(\mathrm{~d}, 2 \mathrm{H}, \mathrm{J}=8.8$ $\left.{ }_{35} \mathrm{~Hz}\right) .{ }^{13} \mathrm{C}$ NMR $\left(75 \mathrm{MHz}, \mathrm{CDCl}_{3}\right): 10.0\left(\mathrm{CH}_{3}\right), 52.1\left(\mathrm{CH}_{3}\right), 126.6$ (2 CH), 130.0 (2 CH), $133.9(\mathrm{C}), 136.3(\mathrm{C}), 136.7(\mathrm{C}), 139.0(\mathrm{C})$, $162.0(\mathrm{C}=\mathrm{O})$. HRMS (ESI): calcd for $\mathrm{C}_{11} \mathrm{H}_{10}{ }^{35} \mathrm{ClN}_{3} \mathrm{NaO}_{2}$ $\left[(\mathrm{M}+\mathrm{Na})^{+\bullet}\right] 274.0359$, found 274.0363 .

Methyl 5-methyl-1-(4-bromophenyl)-1H-1,2,3-triazole-440 carboxylate (3g). Yield: $78 \%$ (general procedure 1), $20 \%$ (general procedure 2). White powder, mp $200{ }^{\circ} \mathrm{C}$. IR (KBr): 665 , 1115, 1561, 1725, 3097. ${ }^{1} \mathrm{H}$ NMR (300 MHz, $\left.\mathrm{CDCl}_{3}\right): 2.60$ (s, $3 \mathrm{H}), 3.99$ (s, 3H), 7.36 (d, 2H, J = $8.4 \mathrm{~Hz}), 7.72(\mathrm{~d}, 2 \mathrm{H}, \mathrm{J}=8.4$ $\mathrm{Hz}) .{ }^{13} \mathrm{C}$ NMR $\left(75 \mathrm{MHz}, \mathrm{CDCl}_{3}\right): 10.0\left(\mathrm{CH}_{3}\right), 52.1\left(\mathrm{CH}_{3}\right), 124.3$ $45(\mathrm{C}), 126.8(2 \mathrm{CH}), 133.0(2 \mathrm{CH}), 134.4(\mathrm{C}), 136.7(\mathrm{C}), 138.9(\mathrm{C})$, $162.0(\mathrm{C}=\mathrm{O})$. HRMS (ESI): calcd for $\mathrm{C}_{11} \mathrm{H}_{10}{ }^{79} \mathrm{BrN}_{3} \mathrm{NaO}_{2}$ $\left[(\mathrm{M}+\mathrm{Na})^{+\bullet}\right] 317.9854$, found 317.9856 .

Methyl 5-methyl-1-(3-nitrophenyl)-1H-1,2,3-triazole-4carboxylate (3h). Yield: $71 \%$ (general procedure 1), $75 \%$ 50 (general procedure 2). Yellow powder, mp $140{ }^{\circ} \mathrm{C}$. IR $(\mathrm{KBr})$ : 1092, 1561, 1736, 3104. ${ }^{1} \mathrm{H}$ NMR (300 MHz, $\left.\mathrm{CDCl}_{3}\right): 2.70$ (s, $3 \mathrm{H}), 4.01(\mathrm{~s}, 3 \mathrm{H}), 7.90(\mathrm{~m}, 2 \mathrm{H}), 8.44(\mathrm{~m}, 2 \mathrm{H}) .{ }^{13} \mathrm{C}$ NMR $(75$ $\left.\mathrm{MHz}, \mathrm{CDCl}_{3}\right): 10.5\left(\mathrm{CH}_{3}\right), 52.6\left(\mathrm{CH}_{3}\right), 120.7(\mathrm{CH}), 125.2(\mathrm{CH})$, $131.4(\mathrm{CH}), 131.4(\mathrm{CH}), 136.7(\mathrm{C}), 137.4(\mathrm{C}), 139.5(\mathrm{C}), 149.1$
$55(\mathrm{C}), 162.2(\mathrm{C}=\mathrm{O})$. HRMS (ESI): calcd for $\mathrm{C}_{11} \mathrm{H}_{10} \mathrm{~N}_{4} \mathrm{NaO}_{4}$ $\left[(\mathrm{M}+\mathrm{Na})^{+\bullet}\right] 285.0600$, found 285.0600 .

\section{1-(4-Nitrophenyl)-5-phenyl-1H-1,2,3-triazole-4-}

(phenylketone) (5a). ${ }^{7 \mathrm{i}}$ Yield: $40 \%$ (general procedure 1), $85 \%$ (general procedure 2 ), $57 \%$ (general procedure 3 ). Beige powder, $60 \mathrm{mp} 172{ }^{\circ} \mathrm{C} .{ }^{1} \mathrm{H}$ NMR (300 MHz, $\left.\left(\mathrm{CD}_{3}\right)_{2} \mathrm{CO}\right): 7.45$ (m, 5H), 7.55 $(\mathrm{m}, 2 \mathrm{H}), 7.67(\mathrm{tt}, 1 \mathrm{H}, \mathrm{J}=7.4$ and $1.4 \mathrm{~Hz}), 7.76(\mathrm{~d}, 2 \mathrm{H}, \mathrm{J}=9.3$ $\mathrm{Hz}), 8.23(\mathrm{dd}, 1 \mathrm{H}, \mathrm{J}=8.4$ and $1.2 \mathrm{~Hz}), 8.37(\mathrm{~d}, 2 \mathrm{H}, \mathrm{J}=9.3 \mathrm{~Hz})$. ${ }^{13} \mathrm{C}$ NMR (75 MHz, $\left.\left(\mathrm{CD}_{3}\right)_{2} \mathrm{CO}\right): 125.1(2 \mathrm{CH}), 126.4(\mathrm{C}), 127.1$ $(2 \mathrm{CH}), 128.7(2 \mathrm{CH}), 128.9(2 \mathrm{CH}), 130.4(\mathrm{CH}), 130.8(2 \mathrm{CH})$, ${ }_{65} 130.8(2 \mathrm{CH}), 133.5(\mathrm{CH}), 137.8(\mathrm{C}), 141.3(\mathrm{C}), 141.9(\mathrm{C}), 144.2$ (C), $148.5(\mathrm{C}), 186.4(\mathrm{C}=\mathrm{O})$.

\section{5-Amino-1-(4-nitrophenyl)-1H-1,2,3-triazole-4-carbonitrile} (5b). ${ }^{31}$ Yield: $61 \%$ (general procedure 1), 59\% (general procedure 2), $70 \%$ after $2 \mathrm{~h}$ reaction time and $87 \%$ after $24 \mathrm{~h}$ reaction time 70 (general procedure 3). Beige powder, mp $204{ }^{\circ} \mathrm{C} .{ }^{1} \mathrm{H}$ NMR (300 $\mathrm{MHz},\left(\mathrm{CD}_{3}\right)_{2} \mathrm{CO}$ ): 6.82 (br s, $\left.2 \mathrm{H}\right), 8.01(\mathrm{~d}, 2 \mathrm{H}, \mathrm{J}=8.7 \mathrm{~Hz}), 8.50$ $(\mathrm{d}, 2 \mathrm{H}, \mathrm{J}=8.7 \mathrm{~Hz}) \cdot{ }^{13} \mathrm{C} \mathrm{NMR}\left(75 \mathrm{MHz},\left(\mathrm{CD}_{3}\right)_{2} \mathrm{CO}\right): 101.9(\mathrm{C})$, 105.0 (C), 114.1 (C), $127.1(2 \mathrm{CH}), 127.4(2 \mathrm{CH}), 141.4(\mathrm{C})$, 149.9 (C). HRMS (EI): calcd for $\mathrm{C}_{9} \mathrm{H}_{8} \mathrm{~N}_{6} \mathrm{O}_{2}\left[\mathrm{M}^{+*}\right] 232.0709$, 75 found 232.0709 .

N-(2-Hydroxyphenyl) 1-(4-nitrophenyl)-4,5-dihydro-1H-1,2,3triazole-4-carboxamide (8). To $N$-(2-hydroxyphenyl)acrylamide (7a, $3 \mathrm{mmol})$ in toluene $(25 \mathrm{~mL})$ was added 4-nitrophenyl azide $(\mathbf{1 a}, 3 \mathrm{mmol})$ and bentonite- $\mathrm{Cu}^{2+}(0.1 \mathrm{~g})$, and the mixture was 80 heated under reflux for $24 \mathrm{~h}$. The precipitate was filtrated, and extracted with acetone. After removal of the solvent, the product was recrystallized from EtOH. Yield: $68 \%$. Yellow powder, mp $196{ }^{\circ} \mathrm{C}$. IR (KBr): 1095, 1596, 1671, 3079, 3198, 3388. ${ }^{1} \mathrm{H}$ NMR $\left(200 \mathrm{MHz},\left(\mathrm{CD}_{3}\right)_{2} \mathrm{SO}\right): 3.40(\mathrm{~d}, 2 \mathrm{H}, \mathrm{J}=11 \mathrm{~Hz}), 5.83(\mathrm{t}, 1 \mathrm{H}, \mathrm{J}=$ $8511 \mathrm{~Hz}), 6.88(\mathrm{~m}, 3 \mathrm{H}), 7.49(\mathrm{~d}, 2 \mathrm{H}, \mathrm{J}=8.6 \mathrm{~Hz}), 7.90(\mathrm{~s}, 1 \mathrm{H}), 8.26$ $(\mathrm{d}, 2 \mathrm{H}, \mathrm{J}=8.6 \mathrm{~Hz}), 9.81(\mathrm{~s}, 1 \mathrm{H}), 10.0(\mathrm{~s}, 1 \mathrm{H}) .{ }^{13} \mathrm{C} \mathrm{NMR}(50$ $\left.\mathrm{MHz},\left(\mathrm{CD}_{3}\right)_{2} \mathrm{SO}\right): 43.8\left(\mathrm{CH}_{2}\right), 81.4(\mathrm{CH}), 114.5,115.4,115.6$, $119.3,122.2,125.4,125.9,126.1,135.9,141.9,145.5,165.4$ $(\mathrm{C}=\mathrm{O})$.

${ }_{90} \mathrm{~N}$-(2-Allyloxyphenyl) 1-(4-nitrophenyl)-4,5-dihydro-1H-1,2,3triazole-4-carboxamide (9). To $N$-(2-allyloxyphenyl)acrylamide $(\mathbf{7 b}, 2 \mathrm{mmol})$ in toluene $(15 \mathrm{~mL})$ was added 4-nitrophenyl azide (1a, $2 \mathrm{mmol})$ and bentonite- $\mathrm{Cu}^{2+}(0.1 \mathrm{~g})$, and the mixture was sonicated for $7 \mathrm{~h}$. The precipitate was filtrated, and extracted with 95 acetone. After removal of the solvent, the product was recrystallized from EtOH. Yield: 33\%. Yellow powder, mp 220 ${ }^{\circ} \mathrm{C}$. IR (KBr): 1115, 1597, 1679, 3080, 3368. ${ }^{1} \mathrm{H}$ NMR (200 MHz, $\left(\mathrm{CDCl}_{3}\right): 3.35(2 \mathrm{~d}, 2 \mathrm{H}, \mathrm{J}=18$ and $19 \mathrm{~Hz}), 3.55(\mathrm{~d}, 1 \mathrm{H}, \mathrm{J}=18$ $\mathrm{Hz}), 3.91(\mathrm{~d}, 1 \mathrm{H}, \mathrm{J}=19 \mathrm{~Hz}), 4.65(\mathrm{~d}, 2 \mathrm{H}, \mathrm{J}=5.6 \mathrm{~Hz}), 5.34(\mathrm{dd}$, $1001 \mathrm{H}, \mathrm{J}=1.3$ and $10 \mathrm{~Hz}), 5.48(\mathrm{dd}, 1 \mathrm{H}, \mathrm{J}=1.3$ and $17 \mathrm{~Hz}), 6.09$ (ddd, $1 \mathrm{H}, \mathrm{J}=5.6,10$ and $17 \mathrm{~Hz}), 6.50(\mathrm{~s}, 1 \mathrm{H}), 6.63(\mathrm{~d}, 2 \mathrm{H}, \mathrm{J}=$ $8.8 \mathrm{~Hz}), 6.90-7.20(\mathrm{~m}, 4 \mathrm{H}), 8.10(\mathrm{dd}, 2 \mathrm{H}, \mathrm{J}=8.8 \mathrm{~Hz}) .{ }^{13} \mathrm{C} \mathrm{NMR}$ $\left(50 \mathrm{MHz}, \mathrm{CDCl}_{3}\right): 46.9\left(\mathrm{CH}_{2}\right), 69.2\left(\mathrm{CH}_{2}\right), 69.3(\mathrm{CH}), 117.6$ $\left(\mathrm{CH}_{2}\right), 119.2(2 \mathrm{CH}), 121.4(\mathrm{CH}), 121.5(\mathrm{CH}), 124.1(2 \mathrm{CH})$, $105124.1(\mathrm{CH}), 124.9(\mathrm{CH}), 129.2(\mathrm{CH}), 147.1(\mathrm{C}), 147.5(\mathrm{C}), 149.0$ (C), $163.2(\mathrm{C}), 181.8(\mathrm{C}=\mathrm{O})$. HRMS (EI): calcd for $\mathrm{C}_{18} \mathrm{H}_{17} \mathrm{~N}_{5} \mathrm{O}_{4}$ $\left[\mathrm{M}^{+\bullet}\right]$ 367.1281, found 367.1281.

1-(1-(4-Nitrophenyl)-4,5-dihydro-1H-1,2,3-triazolyl)-2-

pyrrolidinone (10). To $N$-vinylpyrrolidinone $(7 \mathbf{c}, 5 \mathrm{mmol})$ in 110 acetone $(30 \mathrm{~mL})$ was added 4-nitrophenyl azide (1a, $5 \mathrm{mmol})$, 
and the mixture was heated under reflux for $24 \mathrm{~h}$. The precipitate was filtrated, and the product was recrystallized from EtOH. Yield: $63 \%$. Yellow powder, mp $184{ }^{\circ} \mathrm{C}$. IR (KBr): 1047, 1599, 1685, 3113. ${ }^{1} \mathrm{H}$ NMR (200 MHz, $\left.\mathrm{CDCl}_{3}\right): 1.90$ (m, 2H), 2.35 (m, $\left.{ }_{5} 2 \mathrm{H}\right), 2.62(\mathrm{~m}, 1 \mathrm{H}), 2.96(\mathrm{~m}, 1 \mathrm{H}), 4.44(\mathrm{t}, 2 \mathrm{H}, \mathrm{J}=2.1 \mathrm{~Hz}), 6.38$ $(\mathrm{dd}, 1 \mathrm{H}, \mathrm{J}=4.0$ and $8.3 \mathrm{~Hz}), 7.45(\mathrm{~d}, 2 \mathrm{H}, \mathrm{J}=9.2 \mathrm{~Hz}), 8.22(\mathrm{~d}$, $2 \mathrm{H}, \mathrm{J}=9.2 \mathrm{~Hz}) .{ }^{13} \mathrm{C} \mathrm{NMR}\left(50 \mathrm{MHz}, \mathrm{CDCl}_{3}\right): 17.8\left(\mathrm{CH}_{2}\right), 30.7$ $\left(\mathrm{CH}_{2}\right), 41.7\left(\mathrm{CH}_{2}\right), 58.9\left(\mathrm{CH}_{2}\right), 69.7(\mathrm{CH}), 108.5,114.9,126.4$, 143.4, 143.8, 155.4, 175.9 (C=O). 1-(4-Nitrophenyl)-1H-1,2,310 triazole (11) was obtained instead in $58 \%$ yield using the following procedure: To $N$-vinylpyrrolidinone $(5 \mathrm{mmol})$ was added 4-nitrophenyl azide (1a, $5 \mathbf{m m o l}$ ), and the mixture was microwave-heated at $350 \mathrm{~W}$ for $10 \mathrm{~min}$. The product collected with EtOH was washed and dried. Mp $204{ }^{\circ} \mathrm{C}$ (lit. ${ }^{32} 205-207{ }^{\circ} \mathrm{C}$ ).

\section{${ }_{15}$ Crystallography}

Single crystals suitable for X-ray diffraction were grown after slow evaporation (several days at room temperature) of solutions of $\mathbf{3 b}, \mathbf{3 c}, \mathbf{3 f}$ and $\mathbf{5 a}$ in AcOEt. The samples were studied with graphite monochromatized $\mathrm{Mo}_{\mathrm{K} \alpha}$ radiation $(\lambda=0.71073 \AA)$. X20 ray diffraction data were collected at $T=100(2) \mathrm{K}$ for $\mathbf{3 c}$ and $\mathbf{5 a}$, and at $T=150(2) \mathrm{K}$ for $\mathbf{3 b}$ and 3f, using APEXII Bruker-AXS diffractometer. The structure was solved by direct methods using the SIR97 program, ${ }^{33}$ and then refined with full-matrix leastsquare methods based on $\mathrm{F}^{2}$ (SHELX-97) ${ }^{34}$ with the aid of the ${ }_{25}$ WINGX program. ${ }^{35}$ All non-hydrogen atoms were refined with anisotropic atomic displacement parameters. $\mathrm{H}$ atoms were finally included in their calculated positions. Molecular diagrams were generated by ORTEP-3 (version 1.08). ${ }^{36}$

Crystal data for $3 \mathbf{b}: \mathrm{C}_{11} \mathrm{H}_{10} \mathrm{ClN}_{3} \mathrm{O}, M=235.67$, triclinic, $P-1$, ${ }_{30} a=5.5353(2), b=6.5391(3), c=15.0596(7) \AA, \alpha=85.657(1), \beta$ $=81.972(1), \gamma=89.189(2){ }^{\circ}, V=538.20(4) \AA^{3}, Z=2, d=1.45$ g.cm ${ }^{-3}, \mu=0.335 \mathrm{~mm}^{-1}$. A final refinement on $\mathrm{F}^{2}$ with 2440 unique intensities and 147 parameters converged at $\omega R\left(F^{2}\right)=$ $0.0817(R(F)=0.0302)$ for 2317 observed reflections with $I>$ ${ }_{35} 2 \sigma(I)$.

Crystal data for 3c: $\mathrm{C}_{11} \mathrm{H}_{10} \mathrm{BrN}_{3} \mathrm{O}, M=280.13$, triclinic, $P-1$, $a=5.6105(2), b=6.4884(3), c=15.2886(7) \AA, \alpha=86.338(2), \beta$ $=81.785(2), \gamma=89.249(2){ }^{\circ}, V=549.71(4) \AA^{3}, Z=2, d=1.69$ g.cm ${ }^{-3}, \mu=3.72 \mathrm{~mm}^{-1}$. A final refinement on $\mathrm{F}^{2}$ with 2494 unique 40 intensities and 147 parameters converged at $\omega \mathrm{R}\left(\mathrm{F}^{2}\right)=0.0446$ $(R(F)=0.0179)$ for 2396 observed reflections with $\mathrm{I}>2 \sigma(\mathrm{I})$.

Crystal data for 3f: $2\left(\mathrm{C}_{11} \mathrm{H}_{10} \mathrm{ClN}_{3} \mathrm{O}_{2}\right) ; \quad M=503.34$, orthorhombic, $P b c 2_{1}, a=3.8164(1), b=12.7220(3), c=$

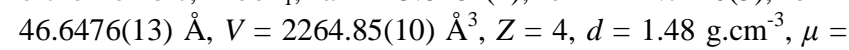
${ }_{45} 0.330 \mathrm{~mm}^{-1}$. A final refinement on $\mathrm{F}^{2}$ with 4171 unique intensities and 311 parameters converged at $\omega \mathrm{R}\left(\mathrm{F}^{2}\right)=0.0874(\mathrm{R}(\mathrm{F})=$ 0.0403 ) for 3781 observed reflections with $\mathrm{I}>2 \sigma(\mathrm{I})$.

Crystal data for 5a: $\mathrm{C}_{21} \mathrm{H}_{14} \mathrm{~N}_{4} \mathrm{O}_{3}, M=370.36$, monoclinic, $C 2 / c, a=28.5149(9), b=8.7547(3), c=14.6996(5) \AA, \beta=$ ${ }_{50} 110.800(2){ }^{\circ}, V=3430.4(2) \AA^{3}, Z=8, d=1.43{\mathrm{~g} . \mathrm{cm}^{-3}, \mu=0.099}^{-1}$ $\mathrm{mm}^{-1}$. A final refinement on $\mathrm{F}^{2}$ with 3847 unique intensities and 253 parameters converged at $\omega \mathrm{R}\left(\mathrm{F}^{2}\right)=0.0905(\mathrm{R}(\mathrm{F})=0.037)$ for 3284 observed reflections with $\mathrm{I}>2 \sigma(\mathrm{I})$.

\section{Computational methods}

${ }_{55}$ All calculations were carried out with the Gaussian 03 suite of programs $^{37}$. DFT calculations were carried out using the $\mathrm{B} \mathrm{LYP}^{38}$ exchange-correlation functionals, together with the standard 6-31G(d) basis set. ${ }^{39}$ The optimizations were carried out using the Berny analytical gradient optimization method. ${ }^{40}$ The 60 stationary points were characterized by frequency calculations in order to verify that TSs have one and only one imaginary frequency. The intrinsic reaction coordinate (IRC) ${ }^{41}$ paths were traced in order to check the energy profiles connecting each TS to the two associated minima of the proposed mechanism using the 65 second order González-Schlegel integration method. ${ }^{42}$ The stationary points were also optimized using the $6-311+\mathrm{G}^{* *}$ basis set. The energy and geometry results are given in Supplementary Material. No significant changes in relative energies and geometries were found. The electronic structures of stationary 70 points were analyzed by the natural bond orbital (NBO) method. ${ }^{43}$

Solvent effects have been considered at the same level of theory by single point energy calculations of the gas-phase structures using a self-consistent reaction field (SCRF) ${ }^{44}$ based on 75 the polarizable continuum model (PCM) of the Tomasi's group. ${ }^{45}$ As polar solvent we selected acetonitrile $(\varepsilon=35.69)$, which has a dielectric constant similar to the experimental solvent, dimethylformamide $(\varepsilon=36.7)$.

The global electrophilicity index, ${ }^{46} \omega$, has been given by the 80 simple expression $\omega=\left(\mu^{2} / 2 \eta\right)(\mathrm{eV})$, in terms of the electronic chemical potential $\mu$ and the chemical hardness $\eta$. Both quantities may be calculated in terms of one of the electron HOMO and LUMO energies, $\varepsilon_{\mathrm{H}}$ and $\varepsilon_{\mathrm{L}}$, as $\mu \approx\left(\varepsilon_{\mathrm{H}}+\varepsilon_{\mathrm{L}}\right) / 2$ and $\eta \approx\left(\varepsilon_{\mathrm{L}}-\varepsilon_{\mathrm{H}}\right)$, respectively. ${ }^{47}$ Recently, we have introduced an empirical 85 (relative) nucleophilicity index, N, based on the HOMO energies obtained within the Kohn-Sham scheme, ${ }^{48}$ defined as $\mathrm{N}=$ $\mathrm{E}_{\mathrm{HOMO}(\mathrm{Nu})}-\mathrm{E}_{\mathrm{HOMO}(\mathrm{TCE})}(\mathrm{eV}) .{ }^{49}$ This nucleophilicity scale takes tetracyanoethylene (TCE) as a reference. Local electrophilicity ${ }^{50}$ and nucleophilicity ${ }^{51}$ indices, $\omega_{\mathrm{k}}$ and $\mathrm{N}_{\mathrm{k}}$,were evaluated using the 90 following expressions: $\omega_{k}=\omega f_{k}^{+}$and $N_{k}=N f_{k}^{-}$where $f_{k}^{+}$and $f_{k}^{-}$are the Fukui functions for a nucleophilic and electrophilic attacks, respectively. ${ }^{52}$

\section{Pharmacology}

Applying the agar plate diffusion technique, ${ }^{24}$ the compounds 95 were screened in vitro for their bactericidal activity against Gram positive bacteria (Staphylococcus aureus) and Gram negative bacteria (Escherichia Coli and Pseudomonas aeroginosa), and for their fungicidal activity against Fusarium oxysporium, Aspergillus niger and Candida albicans. In this method, a 100 standard $5 \mathrm{~mm}$ diameter sterilized filter paper disc impregnated with the compound $(0.3 \mathrm{mg} / 0.1 \mathrm{ml}$ of DMF $)$ was placed on an agar plate seeded with the test organism. The plates were incubated for 24 hours at $37{ }^{\circ} \mathrm{C}$ for bacteria and $28{ }^{\circ} \mathrm{C}$ for fungi. The zone of inhibition of bacterial and fungi growth around the 105 disc was observed.

The compounds were tested against a liver carcinoma cell line (HEPG2). The method applied is similar to that reported by Skehan et al. ${ }^{53}$ using 20 Sulfo-Rhodamine-B stain (SRB). Cells were plated in 96-multiwell plate (104 cells/well) for $24 \mathrm{~h}$ before 110 treatment with the test compound to allow attachment of cell to the wall of the plate. Different concentrations of the compound under test $(0,1.0,2.5,5.0$, and $10 \mu \mathrm{g} / \mathrm{ml})$ were added to the cell monolayer in triplicate wells individual dose, and monolayer cells 
were incubated with the compounds for $48 \mathrm{~h}$ at $37{ }^{\circ} \mathrm{C}$ and in atmosphere of $5 \% \mathrm{CO}_{2}$. After $48 \mathrm{~h}$, cells were fixed, washed and stained with SRB stain, excess stain was washed with acetic acid and attached stain was recovered with Tris-EDTA buffer. Color 5 intensity was measured in an ELISA reader, and the relation between surviving fraction and drug concentration is plotted to get the survival curve of each tumor cell line after the specified compound and the IC50 was calculated.

\section{${ }_{10}$ Acknowledgment}

The authors thank Asmaa Atrous for her contribution to this study. We are grateful to the Spanish Government (project CTQ2009-11027/BQU).

\section{Notes and references}

$15{ }^{a}$ Laboratoire de Synthèse Organique Appliquée, Faculté des Sciences de l'Université, BP 1524 Es-Senia, Oran 31000, Algeria. Fax: +213-041582540; Tel: +213-79175-8768; E-mail: badri_sofi@yahoo.fr

${ }^{b}$ Chimie et Photonique Moléculaires, UMR 6510 CNRS, Université de Rennes 1, Bâtiment 10A, Case 1003, Campus Scientifique de Beaulieu,

2035042 Rennes Cedex, France. Fax: +33-2-2323-6955; Tel: +33-2-2323-

6931; E-mail: florence.mongin@univ-rennes1.fr

${ }^{c}$ Departamento de Química Orgánica, Universidad de Valencia, Dr. Moliner 50, 46100 Burjassot, Valencia, Spain. Fax: +34-9-6354-4328; Tel: +34-9-6354-3106; E-mail: domingo@utopia.uv.es

${ }_{25}{ }^{d}$ Centre de Diffractométrie X, Sciences Chimiques de Rennes, UMR 6226

CNRS, Université de Rennes 1, Bâtiment 10B, Campus Scientifique de Beaulieu, 35042 Rennes Cedex, France.

${ }^{e}$ Department of Chemistry, Faculty of Women for Arts, Science and

Education, Ain Shams University, Asma Fahmy Street, Heleopolis (El-

30 Margany), Cairo, Egypt

$\dagger$ Electronic Supplementary Information (ESI) available: CIF file of $\mathbf{3 b}$ (CCDC 806634), 3c (CCDC 806635), 3f (CCDC 806636), and 5a (CCDC 806637). See DOI: 10.1039/b000000x/

1 R. Huisgen, R. Grashey and J. Sauer, in The Chemistry of Alkenes, 35 Interscience: New York, 1964.

2 (a) A. Padwa, in 1,3-Dipolar Cycloaddition Chemistry, WileyInterscience: New York, 1984, Vols. 1-2; (b) K. V. Gothelf and K. A. Jorgenson, Chem. Rev., 1998, 98, 863-910.

3 (a) H. Wamhoff, in Comprehensive Heterocyclic Chemistry, Eds.: A.

40 R. Katritzky, C. W. Rees and E. F. V. Sciven, Elsevier Science, Oxford, 1996, Vol. 4; (b) T. Eicher, S. Hauptmann and A. Speicher, in The Chemistry of Heterocycles, $2^{\text {nd }}$ ed., Wiley-VCH: Weinheim, Germany, 2003, Chapter 5.44.

4 See for example: (a) A. Da Settimo, O. Livi, P. L. Ferrarini, I. Tonetti 45 and E. Ciabattini, Farmaco, 1979, 34, 371-382; (b) C. Martini, W. Marrucci, A. Lucacchini, G. Biagi and O. Livi, J. Pharm. Sci., 1988, 77, 977-980.

5 See for example: V. R. Kamalraj, S. Senthil and P. Kannan, J. Mol. Struct., 2008, 892, 210-215.

506 (a) O. Dimroth, Chem. Ber., 1902, 35, 1029-1038; (b) F. R. Benson and W. L. Savell, Chem. Rev., 1950, 46, 1-68, and references cited therein.

7 (a) R. Huisgen, R. Knorr, L. Möbius and G. Szeimies, Chem. Ber., 1965, 98, 4014-4021; (b) T. Nozoe, H. Horino and T. Toda,

55 Tetrahedron Lett., 1967, 8, 5349-5353; (c) C. E. Olsen, Acta Chem. Scand., 1973, 27, 1987-2000; (d) A. Da Settimo, O. Livi, G. Biagi, A. Lucacchini and S. Caselli, Farmaco, 1983, 38, 725-737; (e) K. Honda, H. Nakanishi, Y. Nagawa and A. Yabe, J. Chem. Soc., Chem. Commun., 1984, 450-451; ( $f$ ) F. M. Aly, A. S. El-Sayed, A. H.

60 Bedair and S. A. Madboli, Egypt. J. Chem., 1987, 30, 339-344; $(g)$ I. A. Ol'shevskaya, M. Y. Kornilov and M. N. Smirnov, Khim. Geterotsikl. Soedin., 1990, 1120-1123; (h) S. Ghose and T. L. Gilchrist, J. Chem. Soc., Perkin Trans 1, 1991, 775-780; (i) L. Benati, P. C. Montevecchi and P. Spagnolo, Gazz. Chim. Ital., 1992,
122, 249-251; (j) O. Y. Sapozhnikov, V. V. Dyachuk, M. D. Dutov, V. V. Kachala and S. A. Shevelev, Russ. Chem. Bull., 2005, 54, 1331-1334; (k) N. T. Pokhodylo, R. D. Savka, V. S. Matiichuk and N. D. Obushak, Russ. J. Gen. Chem., 2009, 79, 309-314.

8 (a) A. De la Hoz, A. Díaz-Ortiz and F. Langa, in Microwave in 70 Organic Synthesis, Ed.: A. Loupy, $1^{\text {st }}$ ed., Wiley-VCH: Weinhein, 2002, Chap. 9; (b) K. Bougrin, M. Soufiaoui and G. Bashiardes, in Microwave in Organic Synthesis, Ed.: A. Loupy, $2^{\text {nd }}$ ed., WileyVCH: Weinhein, 2006, Vol. 1, Chap. 11.

9 J.-c. Meng, V. V. Fokin and M. G. Finn, Tetrahedron Lett., 2005, 46, $75 \quad 4543-4546$.

10 P. K. Kadaba, Biomedicine \& Pharmacotherapy, 1996, 50, 163-169.

11 (a) W. Broeckx, N. Overbergh, C. Samyn, G. Smets and G. L'Abbé, Tetrahedron, 1971, 27, 3527-3534; (b) G. T. Anderson, J. R. Henry and S. M. Weinreb, J. Org. Chem., 1991, 56, 6946-6948.

8012 (a) F. Texier, A. Derdour, H. Benhaoua, T. Benabdellah and O. Yebdri, Tetrahedron Lett., 1982, 23, 1893-1896; (b) D. Häbich, W. Barth, and M. Rösner, Heterocycles, 1989, 29, 2083-2087; (c) A. Derdour, T. Benabdallah, B. Merah and F. Texier, Bull. Soc. Chim. Fr., 1990, 69-78; (d) D. K. Wedegaertner, R. K. Kattak, I. Harrison and S. K. Cristie, J. Org. Chem., 1991, 56, 4463-4467; (e) V. P. Semenov, Zh. Organich. Khim., 1996, 32, 1627-1656; (f) L. V. Batog, V. Y. Rozhkov, Y. A. Strelenko, O. V. Lebedev and L. I. Khmel'nitskii, Chem. Heterocycl. Comp. (translation of Khim. Geterotsikl. Soedin.), 2000, 36, 343-345; (g) P. Zanirato, J. Chem.

$90 \quad$ Soc., Perkin Trans. 1, 2002, 1420-1425; (h) W.-M. Peng and S.-Z. Zhu, J. Fluorine Chem., 2002, 116, 81-86.

13 H. Fillion and J.-L. Luche, in Synthetic Organic Sonochemistry, Ed.: J.-L. Luche, Plenum Press: New York, 1998, pp. 91-106.

14 S. Caillère, S. Henin and M. Rautureau, in Minéralogie des argiles, 95 Ed.: Masson, Paris, 1982, Part 1 and 2.

15 P. K. Kadaba, J. Org. Chem., 1992, 57, 3075-3078.

16 J.-C. Fan, J. Liang, Y. Wang and Z.-C. Shang, J. Mol. Struct.: THEOCHEM, 2007, 821, 145-152.

17 D. H. Ess and K. N. Houk, J. Am. Chem Soc, 2008, 130, 1018710198.

18 A. K. Chandra, T. Uchimaru and M. T. Nguyen, J. Chem. Soc. Perkin Trans 2, 1999, 2117-2121.

19 K. B. Wiberg, Tetrahedron, 1968, 24, 1083-1096.

20 (a) L. R. Domingo, M. J. Aurell, P. Pérez and R. Contreras, Tetrahedron, 2002, 58, 4417-4423; (b) P. Pérez, L. R. Domingo, M. J. Aurell and R. Contreras, Tetrahedron, 2003, 59, 3117-3125; (c) P. Pérez, L. R. Domingo, A. Aizman and R. Contreras, in Theoretical Aspects of Chemical Reactivity, Ed.: A. Toro-Labbe, Elsevier Science, Amsterdam, 2006, Vol. 19, pp. 167-238.

11021 (a) P. Geerlings, F. De Proft and W. Langenaeker, Chem. Rev., 2003, 103, 1793-1873; (b) D. H. Ess, G. O. Jones and K. N. Houk, Adv. Synth. Catal., 2006, 348, 2337-2361.

22 L. R. Domingo, E. Chamorro and P. Pérez, Eur. J. Org. Chem., 2009, 3036-3044.

11523 For 4-nitrophenyl azide (3n), the $f_{k}^{+}$Fukui functions for nucleophilic attacks were evaluated using the $\mathrm{LUMO}+1$, since those obtained from the LUMO are mainly concentrated to the aromatic ring (see ref. 22).

24 A. W. Bauer, W. W. M. Kirby, J. C. Sherris and M. Turck, Am. J. 120 Clin. Pathol., 1966, 45, 493-496.

25 E. Nolting, O. Michel, Chem. Ber., 1893, 26, 86-87.

26 J. D. Loudon and J. Ogg, J. Chem. Soc., 1955, 739-744.

27 M. D. Bowman, J. R. Schmink, C. M. McGowan, C. M. Kormos and N. E. Leadbeater, Org. Process Res. Dev., 2008, 12, 1078-1088.

12528 N. T. Pokhodylo, Y. O. Teslenko, V. S. Matiychuk and M. K. Obushak, Synthesis, 2009, 2741-2748.

29 H.-S. Dong, H.-C. Wang, Z.-L. Gao, R.-S. Li and F.-H. Cui, J. Heterocycl. Chem., 2010, 47, 389-395.

30 G. L'Abbé and W. Dehaen, Tetrahedron, 1988, 44, 461-469.

13031 (a) G. L'Abbé and L. Beenaerts, Bull. Soc. Chim. Belg., 1989, 98 421-422; (b) A. Dornow and J. Gelberg, Chem. Ber., 1960, 93, 2001-2010.

32 R. Huisgen, L. Moebius and G. Szeimies, Chem. Ber., 1965, 98, $1138-1152$ 
33 A. Altomare, M. C. Burla, M. Camalli, G. Cascarano, C. Giacovazzo, A. Guagliardi, A. G. G. Moliterni, G. Polidori and R. Spagna, J. Appl. Crystallogr., 1999, 32, 115-119.

34 G. M. Sheldrick, Acta Crystallogr., 2008, A64, 112.

535 L. J. Farrugia, J. Appl. Crystallogr., 1999, 32, 837-838.

36 L. J. Farrugia, J. Appl. Crystallogr., 1997, 30, 565.

37 M. J. Frisch, G. W. Trucks, H. B. Schlegel, G. E. Scuseria, M. A. Robb, J. R. Cheeseman, J. Montgomery, J. A. , T. Vreven, K. N. Kudin, J. C. Burant, J. M. Millam, S. S. Iyengar, J. Tomasi, V. Barone, B. Mennucci, M. Cossi, G. Scalmani, N. Rega, G. A. Petersson, H. Nakatsuji, M. Hada, M. Ehara, K. Toyota, R. Fukuda, J. Hasegawa, M. Ishida, T. Nakajima, Y. Honda, O. Kitao, H. Nakai, M. Klene, X. Li, J. E. Knox, H. P. Hratchian, J. B. Cross, C. Adamo, J. Jaramillo, R. Gomperts, R. E. Stratmann, O. Yazyev, A. J. Austin,

15 R. Cammi, C. Pomelli, J. W. Ochterski, P. Y. Ayala, K. Morokuma, G. A. Voth, P. Salvador, J. J. Dannenberg, V. G. Zakrzewski, S. Dapprich, A. D. Daniels, M. C. Strain, O. Farkas, D. K. Malick, A. D. Rabuck, K. Raghavachari, J. B. Foresman, J. V. Ortiz, Q. Cui, A. G. Baboul, S. Clifford, J. Cioslowski, B. B. Stefanov, G. Liu, A. 20 Liashenko, P. Piskorz, I. Komaromi, R. L. Martin, D. J. Fox, T. Keith, M. A. Al-Laham, C. Y. Peng, A. Nanayakkara, M. Challacombe, P. M. W. Gill, B. Johnson, W. Chen, M. W. Wong, C. Gonzalez and J. A. Pople, Gaussian03, 2004.

38 (a) A. D. Becke, J. Chem. Phys., 1993, 98, 5648-5652; (b) C. Lee,

25 W. Yang and R. G. Parr, Phys. Rev. B, 1988, 37, 785-789.

39 W. J. Hehre, L. Radom, P. v. R. Schleyer and J. A. Pople, in Ab initio Molecular Orbital Theory, Wiley, New York, 1986.

40 (a) H. B. Schlegel, J. Comput. Chem., 1982, 3, 214-218; (b) H. B. Schlegel, in Geometry Optimization on Potential Energy Surface,

30 Ed.: D. R. Yarkony, World Scientific Publishing, Singapore, 1994.

41 K. Fukui, J. Phys. Chem., 1970, 74, 4161-4163.

42 (a) C. González and H. B. Schlegel, J. Phys. Chem., 1990, 94, 55235527; (b) C. González and H. B. Schlegel, J. Chem. Phys., 1991, 95, $5853-5860$.

3543 (a) A. E. Reed, R. B. Weinstock and F. Weinhold, J. Chem. Phys., 1985, 83, 735-746; (b) A. E. Reed, L. A. Curtiss and F. Weinhold, Chem. Rev., 1988, 88, 899-926.

44 (a) J. Tomasi and M. Persico, Chem. Rev., 1994, 94, 2027-2094; (b) B. Y. Simkin and I. Sheikhet, in Quantum Chemical and Statistical

40 Theory of Solutions-A Computational Approach, Ellis Horwood, London, 1995, p. 78-101.

45 (a) E. Cances, B. Mennucci and J. Tomasi, J. Chem. Phys., 1997, 107, 3032-3041; (b) M. Cossi, V. Barone, R. Cammi and J. Tomasi, Chem. Phys. Lett., 1996, 255, 327-335; (c) V. Barone, M. Cossi and J. Tomasi, J. Comput. Chem., 1998, 19, 404-417.

46 R. G. Parr, L. von Szentpaly and S. Liu, J. Am. Chem. Soc., 1999, 121, 1922-1924.

47 (a) R. G. Parr and R. G. Pearson, J. Am. Chem. Soc., 1983, 105, 7512-7516; (b) R. G. Parr and W. Yang, in Density Functional

$50 \quad$ Theory of Atoms and Molecules, Oxford University Press, New York, 1989.

48 W. Kohn and L. J. Sham, Phys. Rev. A, 1965, 140, 1133.

49 L. R. Domingo, E. Chamorro and P. Pérez, J. Org. Chem., 2008, 73, $4615-4624$.

5550 L. R. Domingo, M. J. Aurell, P. Perez and R. Contreras, J. Phys. Chem. A, 2002, 106, 6871-6875.

51 P. Pérez, L. R. Domingo, M. Duque-Noreña and E. Chamorro, $J$. Mol. Struct.: THEOCHEM, 2009, 895, 86-91.

52 R. Contreras, P. Fuentealba, M. Galván and P. Pérez, Chem. Phys. 60 Lett., 1999, 304, 405-413.

53 P. Skehan, R. Storeng, D. Scudiero, A. Monks, J. McMahon, D. Vistica, J. T. Warren, H. Bokesch, S. Kenney, M. R. Boyd, J. Natl. Cancer Inst., 1990, 82, 1107-1112.

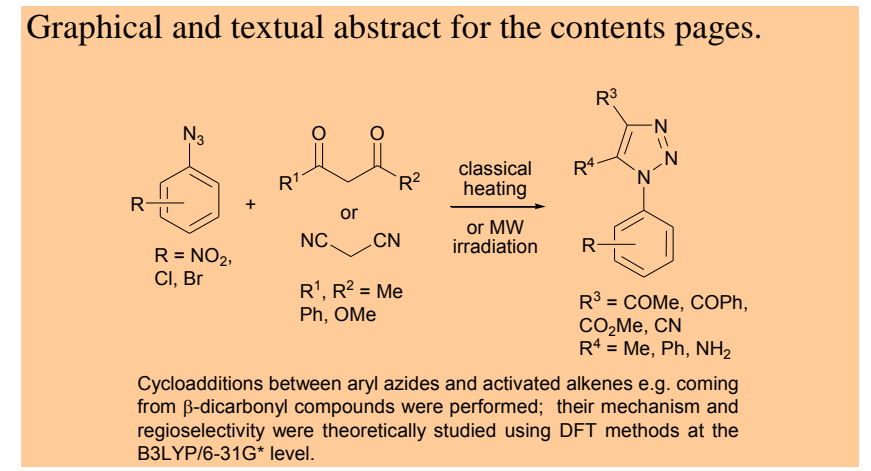

70 